H. CHOUCHANE A.Y. HOEKSTRA M.S. KROL M.M. MEKONNEN

NOVEMBER 2013

\section{WATER FOOTPRINT OF TUNISIA}

\section{FROM AN ECONOMIC PERSPECTIVE}





\title{
WATER FOOTPRINT OF TUNISIA FROM AN ECONOMIC PERSPECTIVE
}

\author{
H. CHOUCHANE ${ }^{1}$ \\ A.Y. HOEKSTRA ${ }^{1, *}$ \\ M.S. KROL ${ }^{1}$ \\ M.M. MEKONNEN ${ }^{1}$
}

NOVEMBER 2013

Value of Water Research Report Series No. 61

\footnotetext{
${ }^{1}$ Twente Water Centre, University of Twente, Enschede, The Netherlands *Contact author: Arjen Y. Hoekstra, a.y.hoekstra@utwente.nl
} 
(C) 2013 The authors

Published by:

UNESCO-IHE Institute for Water Education

P.O. Box 3015

2601 DA Delft

The Netherlands

The Value of Water Research Report Series is published by UNESCO-IHE Institute for Water Education, in collaboration with University of Twente, Enschede, and Delft University of Technology, Delft.

All rights reserved. No part of this publication may be reproduced, stored in a retrieval system, or transmitted, in any form or by any means, electronic, mechanical, photocopying, recording or otherwise, without the prior permission of the authors. Printing the electronic version for personal use is allowed.

Please cite this publication as follows:

Chouchane, H., Hoekstra, A.Y., Krol, M.S. and Mekonnen, M.M. (2013) Water footprint of Tunisia from an economic perspective, Value of Water Research Report Series No. 61, UNESCO-IHE, Delft, the Netherlands. 


\section{Contents}

Summary.

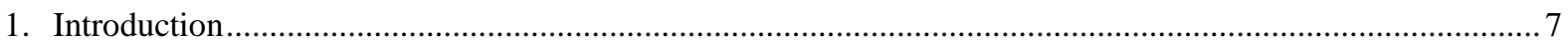

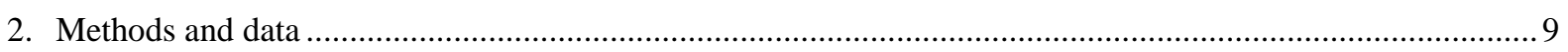

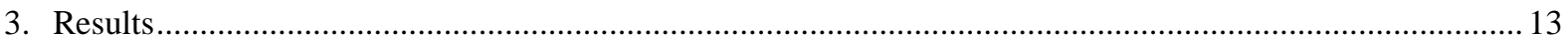

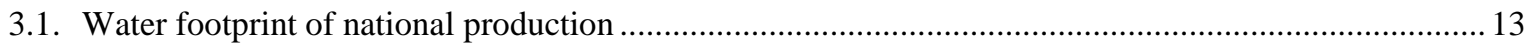

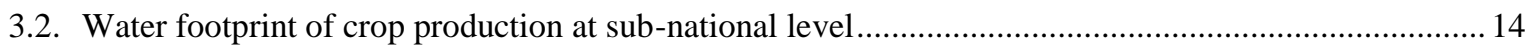

3.3. Blue water footprint of crop production in the context of blue water availability ............................ 17

3.4. Economic water and land productivity at national level ................................................................ 18

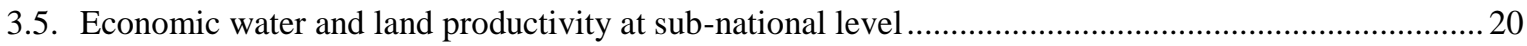

3.6. Virtual water flows related to trade in agricultural and industrial products.....................................23

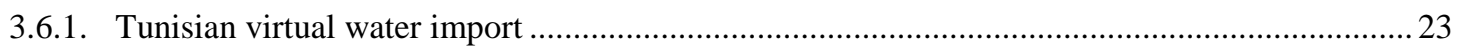

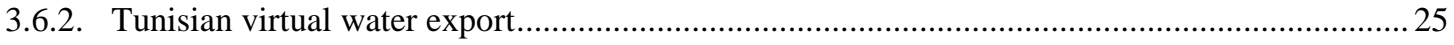

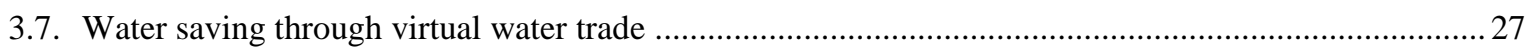

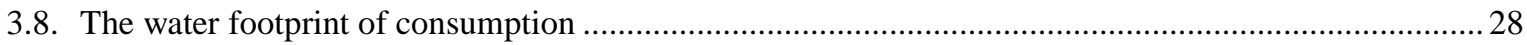

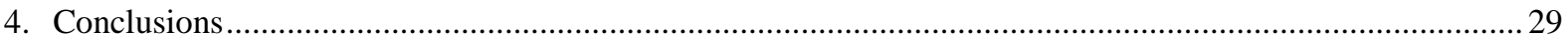

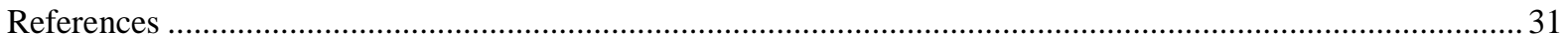





\section{Summary}

In a country where freshwater resources are scarce and unevenly distributed, the choice of cropping patterns and the import of food products can be important means to meet the need for food and lessen the pressure on domestic water resources. This paper quantifies and analyses the water footprint of Tunisia at national and subnational level, assessing green, blue and grey water footprints for the period 1996-2005. It also assesses economic water and land productivities related to crop production for irrigated and rain-fed agriculture and the economic earnings related to export and the economic costs related to import per unit of water virtually traded.

The total water footprint of production in Tunisia was, on average, $19 \mathrm{Gm}^{3} / \mathrm{yr}$ in the period 1996-2005. The water footprint of crop production gave the largest contribution (87\%). North Tunisia has the biggest share in the total water footprint of crop production (70\%), followed by Central (26\%) and South Tunisia (4\%). At national level, tomatoes and potatoes were the main crops with relatively high economic water productivity, with a Tunisian average of 1.08 and $0.87 \mathrm{US} \$ / \mathrm{m}^{3}$ respectively, while olives and barley were the main crops with relatively low productivity, of 0.03 and $0.04 \mathrm{US} \$ / \mathrm{m}^{3}$ respectively. In terms of economic land productivity, oranges had the highest productivity, with 4040 US\$/ha, and barley the lowest, with 130 US\$/ha. South Tunisia has the lowest economic water and land productivities.

The total blue water footprint of crop production represents $31 \%$ of the total renewable blue water resources, which means that Tunisia as a whole experiences significant water scarcity. The blue water footprint resting on groundwater represents $62 \%$ of the total renewable groundwater resources, which means that the country is facing a severe water scarcity related to groundwater. Considering surface and groundwater together, the highest scarcity occurs in South Tunisia (severe water scarcity of 78\%), followed by Central Tunisia (significant water scarcity of 32\%) and finally North Tunisia (moderate water scarcity of 23\%). In terms of groundwater, all regions of the country experience severe water scarcity, with a scarcity level of $47 \%$ for both North and Central Tunisia, while the situation in South Tunisia is even more severe, with a blue WF resting on groundwater exceeding the renewable groundwater resources.

The total water footprint of Tunisian consumption was $21 \mathrm{Gm}^{3} / \mathrm{yr}$, which is $2200 \mathrm{~m}^{3} / \mathrm{yr}$ per citizen. The latter figure is $60 \%$ larger than the world average. Consumption of agricultural products largely determines the total water footprint related to consumption, contributing $98 \%$ to the total water footprint. The study shows that the external water footprint of Tunisian consumption is $32 \%$ of its total water footprint, mainly due to food imports from Europe. 



\section{Introduction}

As one of the most arid countries in the Mediterranean, Tunisia suffers from high water scarcity. The shortage of water resources is a limiting factor to food production. Not only a deliberate management of available resources and choices in agricultural production, but also import of water in virtual form through international trade, seems to be a way to fill the water deficit.

The concept of virtual water (Allan, 1993) is defined as the amount of water embedded in traded products. Water-poor countries can save water by importing water-intensive commodities instead of producing them domestically. International trade in agricultural commodities mainly depends on factors such as availability of land, labour, technology, the costs of engaging in trade, national food policies and international trade agreements (Hoekstra and Chapagain, 2008). Closely linked to the concept of virtual water is the concept of water footprint (WF). The water footprint, introduced by Hoekstra in 2002, is an indicator of fresh water use of a consumer or producer (Hoekstra et al., 2011). The WF informs not only about the level of water consumption but also about where this water is used. The WF of a product is the volume of fresh water used to produce the product, measured over the full supply chain (Hoekstra et al., 2011).

The WF has three components: blue, green and grey. The blue WF refers to consumption of blue water resources (surface and groundwater) in the production process and along the supply chain of a product. The green WF refers to consumption of green water resources (rainwater). The grey WF relates to pollution and is defined as the volume of freshwater that is required to assimilate the load of pollutants given natural background concentrations and existing ambient water quality standards (Hoekstra et al., 2011).

The WF of a crop is generally expressed in terms of $\mathrm{m}^{3} /$ ton or litre/kg, but can also be expressed in terms of $\mathrm{m}^{3}$ per monetary unit (Hoekstra et al., 2011). Garrido et al. (2009) show the usefulness of doing so in a case study for Spain. They show that water scarcity affects water productivity; users become more efficient in their blue water use as water becomes scarcer, but this behavioural adaptation only occurs in regions where water is scarce and where blue water is the main contribution to total crop water use.

A concept closely related to water footprint is water productivity (WP). The increasing scarcity of freshwater and the important role that water plays in food production imposes the need to optimise water use in all human activities, particularly in agriculture, the main water-using sector worldwide. There is no common definition of the term WP (Rodrigues and Pereira, 2009), but in all definitions, WP refers to the ratio of the net benefits from crop, forestry, fishery, livestock or mixed agriculture systems to the amount of water used to produce those benefits. Physical WP can be defined as the ratio of agricultural output to the amount of water consumed ('crop per drop'), which is mostly expressed in either blue water withdrawal or total (green plus blue) water consumption (Kijne et al., 2003; Zwart and Bastiaanssen, 2004, 2007; Playan and Matoes, 2006; Molden, 2007). Expressing WP in physical terms does not give insight in the economic benefit of water use; therefore it is also useful to consider economic water productivity ('dollar per drop') (Cook et al., 2006; Pereira et al., 2009). 
Economic water productivity (EWP) is defined as the value derived per unit of water used (Igbadun et al., 2006; Palanisami et al., 2006; Teixeira et al., 2008; Vazifedoust et al., 2008; Garrido et al., 2009). This definition has also been used to relate water use in agriculture to nutrition, jobs, welfare and environment, where the socioeconomic value added of water use can be expressed in terms of 'nutrition per drop', 'job per drop', etc. The scope for increasing the value per unit of water used in agriculture is often bigger than the scope for increasing physical water productivity (Molden et al., 2010). According to Molden et al. (2010), much of the potential for increasing the harvest for common grains was met during the green revolution. The areas with still a high potential for gains in physical water productivity are those with very low yields, such as sub-Saharan Africa and South Asia. Strategies for increasing the net value of water used in agriculture include: increasing yield, reallocating water from low to higher valued crops or uses, lowering the cost of inputs and increasing the value of ecological services of agriculture and obtaining multiple benefits per unit of water (Molden et al., 2010).

In this report we quantify and analyse the green, blue and grey water footprint within Tunisia, analyse the blue water footprint into the context of blue water availability, assess economic water and land productivities related to crop production for irrigated and rain-fed agriculture, estimate the economic earnings related to export and the economic costs related to import per unit of water virtually traded, and estimate the external water footprint and water dependency of Tunisian consumption. The period of analysis is 1996-2005. The study follows the methodology described in The Water Footprint Assessment Manual (Hoekstra et al., 2011). The study adds to earlier studies of water footprint and virtual water trade for Tunisia (Chapagain and Hoekstra, 2004; Chahed et al., 2008; Chahed et al., 2011; Mekonnen and Hoekstra, 2011a) by adding the economic dimension in a comprehensive national Water Footprint Assessment (WFA). 


\section{Methods and data}

This study follows the terminology and methodology as set out in The Water Footprint Assessment Manual (Hoekstra et al., 2011), which contains the global standard for Water Footprint Assessment (WFA) developed by the Water Footprint Network. The national water footprint accounting scheme shows the various balances that hold for the water footprint related to national consumption, the water footprint within the area of the nation, the virtual water export and the virtual water import (Figure 1).

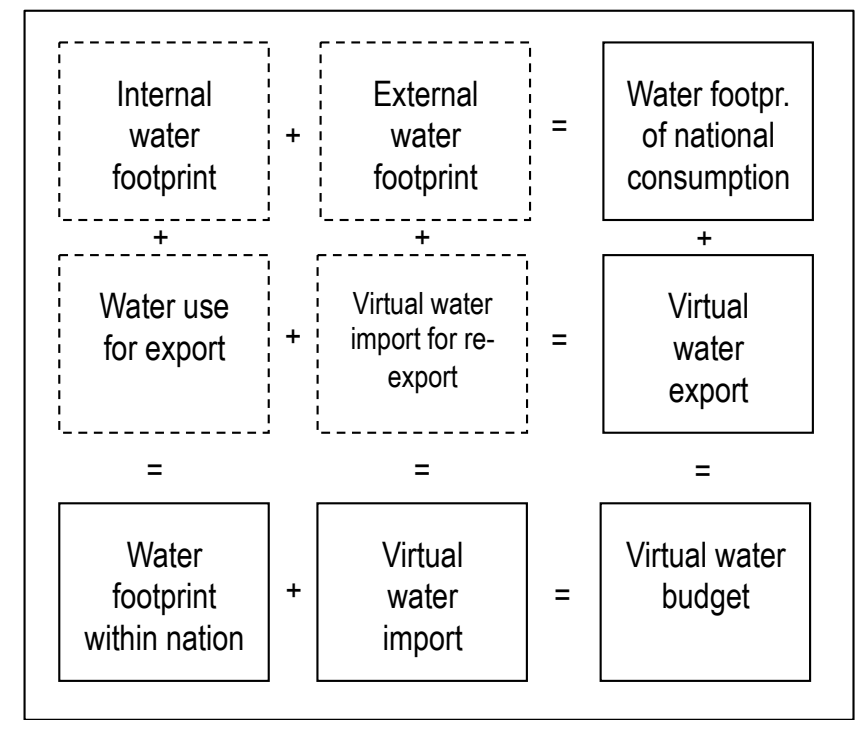

Figure 1. The national water footprint accounting scheme. Source: Hoekstra et al. (2011).

The WF within a nation is defined as the total freshwater volume consumed or polluted within the territory of the nation as a result of different economic activities. The WF of national consumption is defined as the total volume of freshwater that is used to produce the goods and services consumed by the inhabitants of the nation. It consists of two components: the internal and external WF of national consumption. The internal WF is defined as the use of domestic water resources to produce goods and services consumed by the nation's population. It is the sum of the WF within the nation minus the volume of virtual-water export to other nations related to the export of products produced with domestic water resources. The external WF is defined as the volume of water resources used in other nations to produce goods and services consumed by the population in the nation under consideration. It is equal to the virtual-water import into the nation minus the volume of virtualwater export to other nations as a result of re-export of imported products. The virtual-water export from a nation consists of exported water of domestic origin and re-exported water of foreign origin. The virtual-water import into a nation will partly be consumed, thus constituting the external WF of national consumption, and may partly be re-exported. The sum of the virtual water import into a country and the WF within the area of the nation is equal to the sum of the virtual water export from the nation and the WF of national consumption. This sum is called the virtual-water budget of a nation. The national water saving associated with import can be estimated by multiplying the imported product volume by the volume of water that would have been required to produce the product domestically. 
We will put the blue WF in the context of renewable blue water resources (blue water availability) in order to assess water scarcity. Vörösmarty et al. (2000) and Oki and Kanae (2006) consider a country to be severely water stressed if the ratio of blue water withdrawal to renewable blue water resources is higher than $40 \%$. In our case, we will relate water scarcity to the blue WF rather than to blue water withdrawal, which according to Hoekstra et al. (2012) is a more meaningful basis to show water scarcity, since a significant share of withdrawn water returns to rivers and aquifers and becomes available for reuse. The blue WF measures the consumptive use of blue water resources. Following Hoekstra et al. (2012), we compare the blue WF to renewable blue water resources. Table 1 shows the water scarcity thresholds used in this study, equivalent to the thresholds used by Hoekstra et al. (2012).

Table 1. Water scarcity thresholds.

\begin{tabular}{lc}
\hline Blue water scarcity levels * & Water scarcity thresholds \\
\hline Low blue water scarcity & $<20 \%$ \\
Moderate blue water scarcity & $20-30 \%$ \\
Significant blue water scarcity & $30-40 \%$ \\
Severe water scarcity & $>40 \%$ \\
\hline
\end{tabular}

*Water scarcity defined as blue water footprint / renewable blue water resources.

We calculate overall water scarcity on annual basis as the ratio of total blue WF to total renewable blue water resources, and groundwater scarcity as the ratio of the blue WF from groundwater sources to renewable groundwater resources.

In calculating water productivities, we make a distinction between rain-fed and irrigated agriculture. In the former case, the only water source is rainwater, so that we can speak about green water productivity. In the case of irrigated agriculture, we distinguish between green and blue water productivity, because both rainwater and irrigation water are consumed. In irrigated agriculture, green water productivity is defined as the yield that would be obtained based on rain only (assuming that there is no irrigation) divided by the volume of green water consumed. Blue water productivity is defined as the additional yield obtained through irrigation divided by the blue water (irrigation water) evapotranspiration (Hoekstra, 2013).

The yield obtained from rain only is estimated based on the equation proposed by Doorenbos and Kassam (1979):

$\left(1-\frac{\mathrm{Y}_{\mathrm{a}}}{\mathrm{Y}_{\mathrm{m}}}\right)=\mathrm{K}_{\mathrm{y}}\left(1-\frac{\mathrm{ET}_{\mathrm{a}}}{\mathrm{CWR}}\right)$

where $K_{y}$ is a yield response factor (water stress coefficient), $Y_{a}$ the actual yield (kg/ha), $Y_{m}$ the maximum yield, obtained under optimal water supply conditions $(\mathrm{kg} / \mathrm{ha}), \mathrm{ET}_{\mathrm{a}}$ the actual crop evapotranspiration (mm/period) and CWR the crop water requirement $\left(\mathrm{mm} /\right.$ period). Following this equation, the green-water based yield $\left(\mathrm{Y}_{\text {green, irrig }}\right)$ in irrigated agriculture can be calculated from: 
$\left(1-\frac{\mathrm{Y}_{\text {green,irrig }}}{\mathrm{Y}_{\text {tot,irrig }}}\right)=\mathrm{K}_{\mathrm{y}}\left(1-\frac{\mathrm{ET}_{\text {green }}}{\mathrm{ET}_{\text {green }}+\mathrm{ET}_{\text {blue }}}\right)$

whereby $\mathrm{Y}_{\text {tot,irrig }}$ is the yield occurring under full irrigation (rain + irrigation water), which is equal to the maximum yield $\mathrm{Y}_{\mathrm{m}}$; $\mathrm{ET}_{\text {green }}$ is the evapotranspiration of green water that would have occurred without irrigation; $\mathrm{ET}_{\text {blue }}$ is the evapotranspiration of blue water. Data on $\mathrm{Y}_{\text {tot,irrig }}, \mathrm{ET}_{\text {green }}, \mathrm{ET}_{\text {blue }}$ and $\mathrm{K}_{\mathrm{y}}$ are obtained for all irrigated crop areas from the grid-based study of Mekonnen and Hoekstra (2010).

The additional yield through irrigation is calculated as the total yield in irrigated agriculture ( $\mathrm{Y}_{\text {tot,irrig }}$ ) minus the yield that would have hypothetically occurred if there were no irrigation ( $\left.\mathrm{Y}_{\text {green,irrig }}\right)$.

Figure 2 shows the relation between yield and evapotranspiration during the growing period and visualizes green and blue water productivity through two subsequent slopes. The first (green) slope represents the green water productivity, while the second (blue) slope represents the blue water productivity.

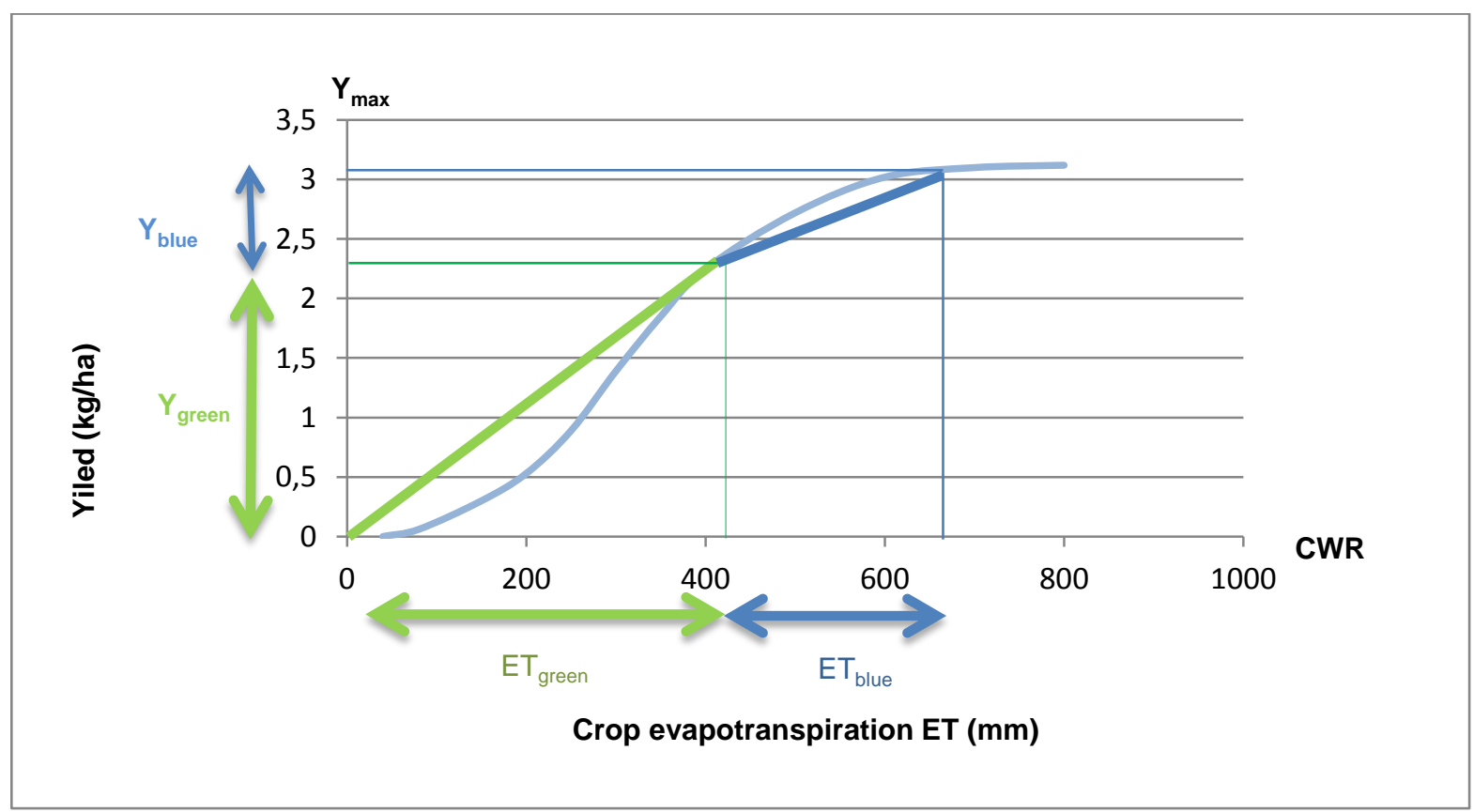

Figure 2. The relation between yield and evapotranspiration from a crop field. Green and blue water productivity appear as the slopes of each of the two line segments drawn in the graph.

Economic water productivities $\left(\mathrm{US} \$ / \mathrm{m}^{3}\right)$ are calculated by multiplying physical water productivities $\left(\mathrm{kg} / \mathrm{m}^{3}\right) \mathrm{by}$ crop value (US\$/kg). For a farmer, economic blue water productivity may be a relevant variable for production decisions, as blue water use goes along with direct production costs or blue water availability may be limiting production. Land productivity may influence decisions on crop choices if land availability is most limiting for a farmer.

The cost per unit of virtual water imported $\left(\mathrm{US} \$ / \mathrm{m}^{3}\right)$ is calculated by dividing the total value of imported crop by its total WF. In a similar way, the earning per unit of virtual water exported $\left(\mathrm{US} \$ / \mathrm{m}^{3}\right)$ is calculated by dividing the total value of exported crop by its total WF. 
The study is based on data for the period of 1996-2005. Table 2 gives an overview of all variables and sources used in this study. We divided the country into three regions based on climate: North, Central and South (Figure 3). North has a Mediterranean climate, South has a Sahara climate, while Central has a climate in between. Each region consists of governorates, administrative sub-units.

Table 2. Overview of input variables and sources used.

\begin{tabular}{ll}
\hline Input variable & Source \\
\hline Water footprint of crop production & Mekonnen and Hoekstra (2010, 2011b) \\
Water footprint in other sectors & Mekonnen and Hoekstra (2011a) \\
Yields and evapotranspiration in rain-fed and irrigated systems & Mekonnen and Hoekstra (2010) \\
Water resources availability and water withdrawal at national level & Ministry of Environment (2009) \\
Surface water availability and withdrawal at regional level & Ministry of Agriculture (2005a) \\
Groundwater availability and withdrawal at regional level & Ministry of Agriculture (2005b) \\
Crop values (producer prices) & FAOSTAT (FAO, 2009) \\
Virtual water flows & Hoekstra and Mekonnen (2012) \\
Economic values of imports and exports & ITC (2007) \\
Water footprint of national consumption & Hoekstra and Mekonnen (2012) \\
\hline
\end{tabular}

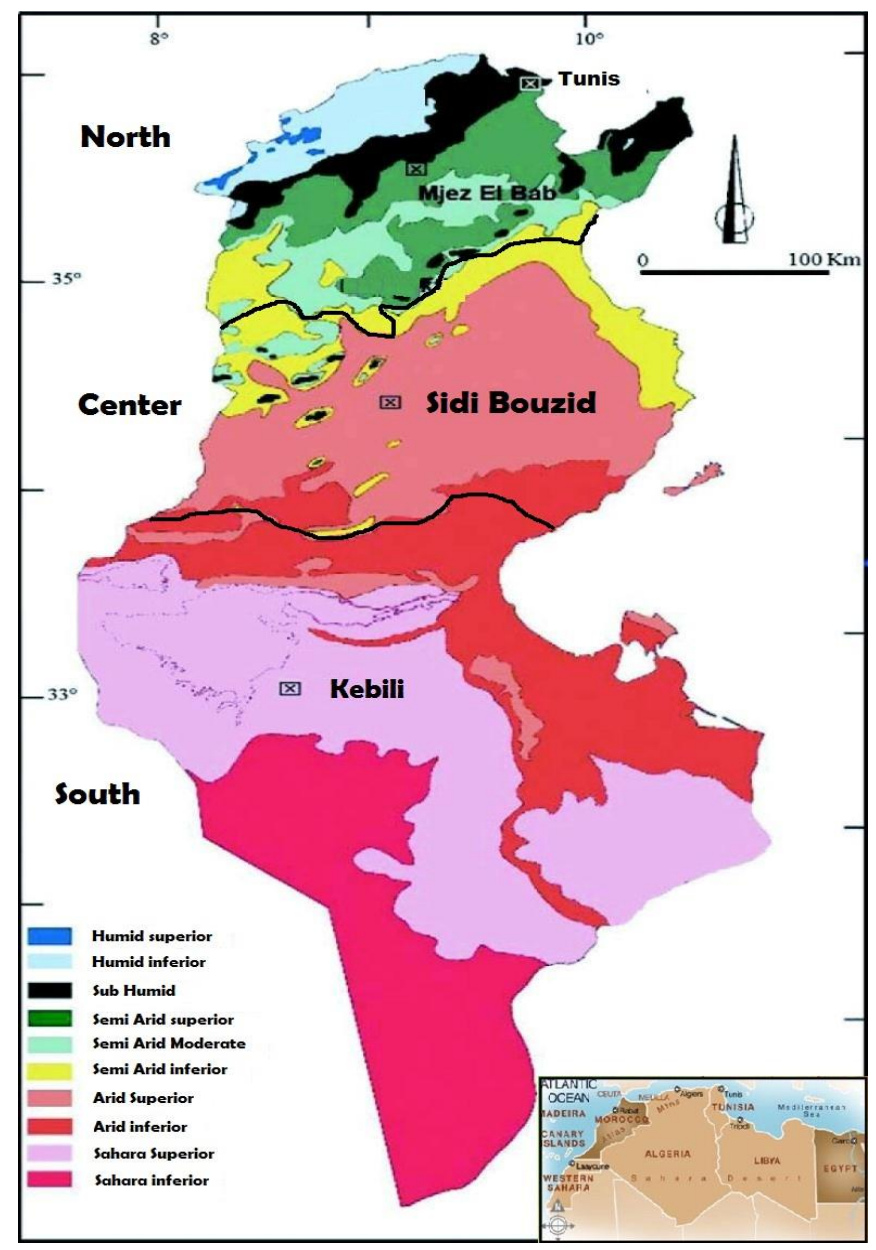

Figure 3. Bioclimatic map of Tunisia. Source: Chelbi et al. (2009). 


\section{Results}

\subsection{Water footprint of national production}

The total water footprint (WF) of Tunisian production was about $19 \mathrm{Gm}^{3} / \mathrm{yr}$ (89\% green, $8 \%$ blue, $3 \%$ grey; see Table 3) over the period 1996-2005. The WF of crop production gave the largest contribution to the total WF of production $(87 \%)$, followed by grazing $(11 \%)$. The remaining part $(2 \%)$ represents domestic water supply, livestock production and industrial activities.

Table 3. The national water footprint of Tunisia and its components ( $\left.\mathrm{Mm}^{3} / \mathrm{yr}\right)$. Period 1996-2005.

\begin{tabular}{|c|c|c|c|c|c|c|}
\hline & $\begin{array}{c}\text { Water footprint } \\
\text { of crop } \\
\text { production }\end{array}$ & $\begin{array}{l}\text { Water } \\
\text { footprint of } \\
\text { grazing }\end{array}$ & $\begin{array}{c}\text { Water } \\
\text { footprint of } \\
\text { animal water } \\
\text { supply }\end{array}$ & $\begin{array}{l}\text { Water footprint } \\
\text { of industrial } \\
\text { production }\end{array}$ & $\begin{array}{c}\text { Water } \\
\text { footprint of } \\
\text { domestic } \\
\text { water supply }\end{array}$ & $\begin{array}{c}\text { Total water } \\
\text { footprint }\end{array}$ \\
\hline Green & 14820 & 2000 & - & - & - & 16820 \\
\hline Blue & 1330 & - & 60 & 10 & 40 & 1440 \\
\hline Grey & 450 & - & - & 50 & 220 & 720 \\
\hline Total & 16600 & 2000 & 60 & 60 & 260 & 19000 \\
\hline
\end{tabular}

Source: Mekonnen and Hoekstra (2011a).

Considering the WF of crops per unit of weight $\left(\mathrm{m}^{3} /\right.$ ton), pistachios had the largest WF, about $98000 \mathrm{~m}^{3} /$ ton, which is much more than the global average of $11000 \mathrm{~m}^{3} /$ ton. The smallest WF of crops was found for lettuce and chicory, about $80 \mathrm{~m}^{3} /$ ton, which is less than the world global average $\left(200 \mathrm{~m}^{3} / \mathrm{ton}\right)$ (Appendix I).

The WFs of the main crops in terms of total national production are listed in Table 4. The listed crops represent $86 \%$ of the total blue WF of crop production. Among these crops, almonds have the largest WF per unit of weight, about $20820 \mathrm{~m}^{3} /$ ton, which is more than twice the global average WF for almonds. Tunisian almonds use about four times more green water compared to the global average, while they consume about the global average amount of blue water. Tomatoes have the smallest WF with $120 \mathrm{~m}^{3} /$ ton, which is below the global average $\left(210 \mathrm{~m}^{3} /\right.$ ton $)$. Dates, almonds, figs and grapes are the biggest blue water users with 3270, 1950, 1740 and $1080 \mathrm{~m}^{3} /$ ton respectively. These figures are higher than the global average, especially for grapes, which uses ten times the global average amount of blue water.

Olives alone account for about $46 \%$ of the total WF of crop production in Tunisia. About $79 \%$ of the total green WF is due to the production of olives $\left(7270 \mathrm{Mm}^{3} / \mathrm{yr}\right.$ ), wheat $\left(3170 \mathrm{Mm}^{3} / \mathrm{yr}\right)$ and barley $\left(1220 \mathrm{Mm}^{3} / \mathrm{yr}\right)$ (Appendix II). The total blue WF is dominated by dates and olives (together 47\%) and, to a lesser extent grapes, wheat and almonds. 
Table 4. The average green, blue and grey water footprint of main crops in Tunisia (1996-2005).

\begin{tabular}{|c|c|c|c|c|c|c|c|c|c|c|c|c|}
\hline \multirow{2}{*}{ Crop } & \multicolumn{4}{|c|}{$\begin{array}{c}\text { Total water footprint } \\
\left(\mathrm{Mm}^{3} / \mathrm{yr}\right)\end{array}$} & \multicolumn{4}{|c|}{$\begin{array}{l}\text { Water footprint per ton of crop } \\
\qquad\left(\mathrm{m}^{3} / \text { ton }\right)\end{array}$} & \multicolumn{4}{|c|}{$\begin{array}{l}\text { Global average water footprint } \\
\qquad\left(\mathrm{m}^{3} / \text { ton }\right)\end{array}$} \\
\hline & Green & Blue & Grey & Total & Green & Blue & Grey & Total & Green & Blue & Grey & Total \\
\hline Almonds & 790 & 90 & 50 & 930 & 17760 & 1950 & 1110 & 20820 & 4630 & 1910 & 1510 & 8050 \\
\hline Barley & 1220 & 30 & 60 & 1310 & 3560 & 80 & 180 & 3820 & 1210 & 80 & 130 & 1420 \\
\hline Carrots & 10 & 30 & 2 & 40 & 260 & 530 & 30 & 820 & 110 & 30 & 60 & 200 \\
\hline Dates & 110 & 350 & 10 & 470 & 1030 & 3270 & 80 & 4390 & 930 & 1250 & 100 & 2280 \\
\hline Figs & 70 & 40 & 4 & 120 & 2810 & 1740 & 170 & 4720 & 1500 & 1540 & 280 & 3280 \\
\hline Grapes & 70 & 130 & 10 & 200 & 550 & 1080 & 60 & 1690 & 430 & 100 & 90 & 610 \\
\hline Olives & 7270 & 270 & 30 & 7570 & 8790 & 330 & 40 & 9150 & 2470 & 500 & 50 & 3010 \\
\hline Oranges & 40 & 20 & 2 & 70 & 370 & 230 & 20 & 620 & 400 & 110 & 50 & 560 \\
\hline Potatoes & 40 & 40 & 10 & 80 & 110 & 120 & 20 & 260 & 190 & 30 & 60 & 290 \\
\hline Tomatoes & 50 & 40 & 10 & 100 & 60 & 50 & 10 & 120 & 110 & 60 & 40 & 210 \\
\hline Wheat & 3170 & 100 & 150 & 3420 & 2380 & 70 & 110 & 2560 & 1280 & 340 & 210 & 1830 \\
\hline
\end{tabular}

Source: Mekonnen and Hoekstra (2011a). Note that ton refers to metric ton.

\subsection{Water footprint of crop production at sub-national level}

The total water footprint of crop production in Tunisia is about $16.6 \mathrm{Gm}^{3} / \mathrm{yr}$. In this total, green water takes the biggest share (89\%), while the blue and grey components contribute $8 \%$ and $3 \%$ respectively. North Tunisia takes the biggest share in the total WF of crop production (70\%), followed by Central (26\%) and South (4\%) (Table 5; Figure 4). Kairouan in Central Tunisia is the governorate with the largest crop-related WF, with 2.2 $\mathrm{Gm}^{3} / \mathrm{yr}$, which represents $13 \%$ of the crop-related WF in the whole country and half of the Central Tunisian WF. The governorates in the surroundings of the river basin Medjerda, such as Beja, Jandouba, Kef and Siliana, had the largest WF in the North of the country and together account for almost $7 \mathrm{Gm}^{3} / \mathrm{yr}$, which represent $43 \%$ of the total WF of crop production in Tunisia. Regarding blue water, North Tunisia has the biggest share in the total blue WF, with $650 \mathrm{Mm}^{3} / \mathrm{yr}$, which represent $49 \%$ of the total blue WF of crop production in the country. South and Central Tunisia follow with $28 \%$ and $23 \%$ respectively. In South Tunisia, the driest part of the country, the total WF of crop production is dominated by blue water (with a contribution of 68\%). The governorates Gabes and Tozeur have the biggest blue WF, mainly because of the production of dates.

Table 6 shows the WF per unit of weight for the most important crops, averaged over the regions North, Central and South. There is a clear difference in WFs and crop water requirements between the three regions. While the difference between North and Central is not so big, results for North and South differ considerably, especially for olives, wheat, almonds, figs and barley. In terms of the blue WF, a unit of wheat or barley grown in South Tunisia uses almost 12 times more blue water than the same crop grown in North, largely because irrigation is the dominant production system in South, whereas rain-fed production is dominant in Central and North. Almond and figs grown in Central Tunisia use less blue water than in the other regions, while tomatoes and carrots grown in South Tunisia have the smallest blue WF per ton. 
Table 5. The total water footprint of crop production in Tunisia by governorate (1996-2005).

\begin{tabular}{|c|c|c|c|c|}
\hline \multirow{2}{*}{ Governorate* $^{*}$} & \multicolumn{4}{|c|}{ Water footprint of crop production $\left(\mathrm{Mm}^{3} / \mathrm{yr}\right)$} \\
\hline & Green & Blue & Grey & Total \\
\hline Ariana & 730 & 140 & 30 & 910 \\
\hline Beja & 1500 & 70 & 50 & 1620 \\
\hline Bizerte & 1110 & 100 & 50 & 1260 \\
\hline Jendouba & 1140 & 90 & 40 & 1270 \\
\hline Kef & 1930 & 40 & 60 & 2030 \\
\hline Nabeul & 960 & 120 & 30 & 1120 \\
\hline Siliana & 1980 & 50 & 50 & 2080 \\
\hline Tunis & 30 & 2 & 1 & 30 \\
\hline Zaghouan & 1270 & 30 & 30 & 1330 \\
\hline North Tunisia & 10650 & 650 & 340 & 11640 \\
\hline Kairouan & 1990 & 160 & 50 & 2190 \\
\hline Kasserine & 930 & 20 & 30 & 980 \\
\hline Mahdia & 1 & 1 & 0 & 2 \\
\hline Monastir & 70 & 3 & 1 & 80 \\
\hline Sfax & 210 & 40 & 8 & 250 \\
\hline SidiBouzid & 280 & 70 & 8 & 360 \\
\hline Sousse & 520 & 9 & 7 & 540 \\
\hline Central Tunisia & 4000 & 290 & 100 & 4390 \\
\hline Gabes & 100 & 180 & 6 & 280 \\
\hline Gafsa & 3 & 8 & 0 & 10 \\
\hline Kebili & 2 & 9 & 0 & 10 \\
\hline Medenine & 0 & 1 & 0 & 1 \\
\hline Tataouine & 1 & 3 & 0 & 4 \\
\hline Tozeur & 60 & 190 & 5 & 250 \\
\hline South Tunisia & 160 & 390 & 10 & 560 \\
\hline
\end{tabular}

Source: Mekonnen and Hoekstra (2011b).

* Tunisia is subdivided into 24 governorates; Manouba and Ben Arous are relatively new and are accounted in this study under Tunis (the capital).
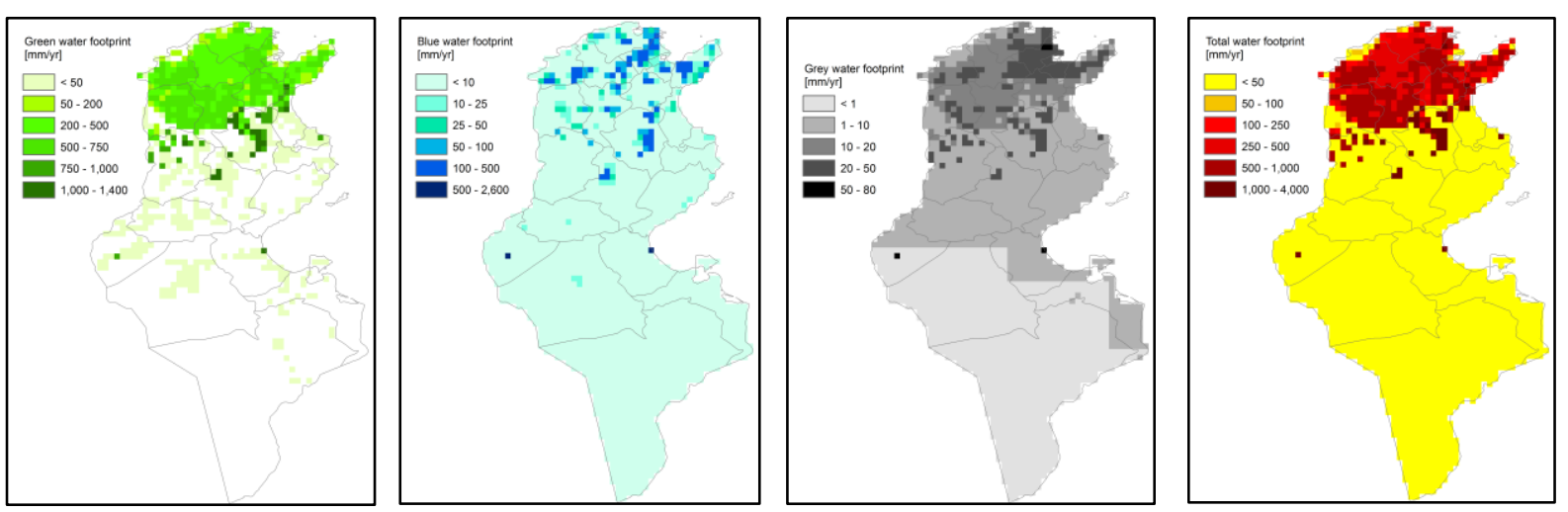

Figure 4. The green, blue, grey and total water footprint of crop production in Tunisia. 
Table 6. The average green, blue and grey water footprint and crop water requirement of main crops in Tunisia per region (1996-2005).

\begin{tabular}{|c|c|c|c|c|c|c|c|c|c|c|}
\hline & \multirow{2}{*}{ Crop } & \multicolumn{4}{|c|}{ Water footprint per ton of crop ( $\mathrm{m}^{3} /$ ton $)$} & \multicolumn{4}{|c|}{ Total water footprint $\left(\mathrm{Mm}^{3} / \mathrm{yr}\right)$} & \multirow{2}{*}{$\begin{array}{c}\text { Crop water } \\
\text { requirement } \\
\left(\mathrm{m}^{3} / \mathrm{ha}\right)\end{array}$} \\
\hline & & Green & Blue & Grey & Total & Green & Blue & Grey & Total & \\
\hline \multirow{11}{*}{$\begin{array}{l}\frac{c}{ \pm} \\
\frac{1}{2}\end{array}$} & Almonds & 16590 & 2480 & 1010 & 20090 & 380 & 60 & 20 & 460 & 9220 \\
\hline & Barley & 3520 & 90 & 180 & 3790 & 930 & 10 & 50 & 990 & 4570 \\
\hline & Carrots & 290 & 500 & 40 & 820 & 10 & 20 & 1 & 30 & 6340 \\
\hline & Dates & - & - & - & - & - & - & - & - & - \\
\hline & Figs & 2840 & 1680 & 170 & 4690 & 60 & 40 & 4 & 110 & 7780 \\
\hline & Grapes & 780 & 1120 & 70 & 1970 & 30 & 40 & 3 & 70 & 7160 \\
\hline & Olives & 8650 & 400 & 40 & 9080 & 4660 & 170 & 20 & 4850 & 8150 \\
\hline & Oranges & 370 & 220 & 20 & 610 & 40 & 20 & 2 & 60 & 7780 \\
\hline & Potatoes & 130 & 110 & 20 & 260 & 30 & 40 & 10 & 70 & 3550 \\
\hline & Tomatoes & 70 & 40 & 10 & 120 & 40 & 30 & 10 & 70 & 3510 \\
\hline & Wheat & 2360 & 90 & 110 & 2550 & 2820 & 70 & 130 & 3020 & 4980 \\
\hline \multirow{11}{*}{ 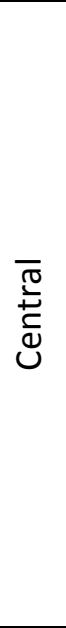 } & Almonds & 18290 & 1490 & 1200 & 20980 & 410 & 30 & 30 & 470 & 9550 \\
\hline & Barley & 3470 & 240 & 200 & 3910 & 290 & 10 & 20 & 320 & 4710 \\
\hline & Carrots & 490 & 380 & 70 & 940 & 3 & 7 & 0 & 10 & 6650 \\
\hline & Dates & - & - & - & - & - & - & - & - & - \\
\hline & Figs & 3460 & 1200 & 220 & 4880 & 10 & 10 & 1 & 10 & 8030 \\
\hline & Grapes & 700 & 1300 & 70 & 2060 & 30 & 50 & 3 & 90 & 7510 \\
\hline & Olives & 8840 & 470 & 40 & 9350 & 2580 & 100 & 10 & 2690 & 8420 \\
\hline & Oranges & 370 & 240 & 20 & 630 & 3 & 3 & 0 & 10 & 8020 \\
\hline & Potatoes & 110 & 130 & 20 & 270 & 10 & 20 & 0 & 40 & 3660 \\
\hline & Tomatoes & 80 & 40 & 10 & 120 & 10 & 10 & 2 & 20 & 3640 \\
\hline & Wheat & 2350 & 230 & 120 & 2710 & 350 & 20 & 20 & 390 & 5120 \\
\hline \multirow{11}{*}{ 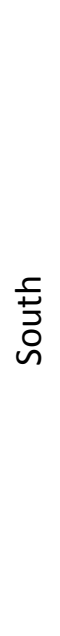 } & Almonds & 20810 & 2330 & 2080 & 25220 & 10 & 1 & 1 & 10 & 11780 \\
\hline & Barley & 3770 & 1050 & 310 & 5130 & 2 & 1 & 0 & 3 & 6070 \\
\hline & Carrots & 670 & 30 & 150 & 860 & 0 & 0 & 0 & 0 & 7760 \\
\hline & Dates & 1040 & 3290 & 80 & 4390 & 110 & 350 & 10 & 470 & 13350 \\
\hline & Figs & 4940 & 820 & 500 & 6260 & 0 & 0 & 0 & 0 & 9920 \\
\hline & Grapes & 450 & 1870 & 70 & 2380 & 10 & 30 & 1 & 40 & 8730 \\
\hline & Olives & 10750 & 930 & 80 & 11760 & 30 & 3 & 0 & 40 & 10390 \\
\hline & Oranges & 210 & 510 & 30 & 750 & 0 & 0 & 0 & 0 & 9480 \\
\hline & Potatoes & 70 & 210 & 30 & 310 & 0 & 0 & 0 & 0 & 4310 \\
\hline & Tomatoes & 150 & 1 & 20 & 170 & 0 & 0 & 0 & 0 & 4500 \\
\hline & Wheat & 2780 & 1230 & 210 & 4220 & 3 & 1 & 0 & 4 & 6610 \\
\hline
\end{tabular}

Source: Mekonnen and Hoekstra (2011b). 


\subsection{Blue water footprint of crop production in the context of blue water availability}

Tunisia has limited water resources, estimated at $4.87 \mathrm{Gm}^{3} / \mathrm{yr}$ in 2005 , of which $4.26 \mathrm{Gm}^{3} / \mathrm{yr}$ are renewable (Ministry of Environment, 2009). The remaining part, $610 \mathrm{Mm}^{3} / \mathrm{yr}$, is fossil groundwater situated in South Tunisia, and expected to be exhausted in about 50 years at the current extraction rate (FAO, 2003).

The total renewable surface water (TRSW) was estimated at $2.70 \mathrm{Gm}^{3} / \mathrm{yr}$ (Table 7). This amount represents the average calculated over a 50-year period. Surface water contributions come from four distinct natural regions. The far northern part of North Tunisia, with only 3\% of the total Tunisian land area, has on average about 960 $\mathrm{Mm}^{3} / \mathrm{yr}$ of TRSW, which is about $36 \%$ of the national total. The basins of Majerda and Melian in North Tunisia provide an average of $1.23 \mathrm{Gm}^{3} / \mathrm{yr}$ ( $45 \%$ of the national total). Central Tunisia, including the watersheds Nebhana, Marguellil, Zeroud and Sahel, has an average TRSW of $320 \mathrm{Mm}^{3} / \mathrm{yr}$ (12\%). South Tunisia, which represents about $62 \%$ of the total national land area, has very irregularly available surface water resources, averaging $190 \mathrm{Mm}^{3} / \mathrm{yr}$, or $7 \%$ of the national TRSW (Ministry of Environment, 2009).

The total groundwater resources are estimated at $2.17 \mathrm{Gm}^{3} / \mathrm{yr}$ in 2005 (Ministry of Environment, 2009), of which $750 \mathrm{Mm}^{3} / \mathrm{yr}$ are from shallow aquifers (depth less than $50 \mathrm{~m}$ ) and $1420 \mathrm{Mm}^{3} / \mathrm{yr}$ from deep aquifers (deeper than $50 \mathrm{~m}$ ) of which $610 \mathrm{Mm}^{3} / \mathrm{yr}$ are non-renewable. The total renewable groundwater is thus 1560 $\mathrm{Mm}^{3} / \mathrm{yr}$. North Tunisia has $50 \%$ of the shallow aquifer resources; Central Tunisia contains 33\%, while South contains $17 \%$. Regarding deep aquifers, South has the biggest share (55\%), followed by Central (23\%) and North $(22 \%)$.

In 2005, the total fresh water withdrawal in Tunisia reached $2.65 \mathrm{Gm}^{3} / \mathrm{yr}$, consisting of $0.70 \mathrm{Gm}^{3} / \mathrm{yr}$ surface water withdrawal and $1.95 \mathrm{Gm}^{3} / \mathrm{yr}$ groundwater withdrawal (Ministry of Environment, 2009). Not all abstracted water evaporates, so that part of the water used remains available in the country for reuse. When we want to compare water use to available water resources, it is better to compare the consumptive water use, i.e. the blue water footprint, to the available water resources. On a national scale, the total blue water footprint of crop production is $1.33 \mathrm{Gm}^{3} / \mathrm{yr}$, against a total renewable blue water resources of about $4.26 \mathrm{Gm}^{3} / \mathrm{yr}$. The total blue WF of crop production thus represents $31 \%$ of the total renewable blue water resources, which means that Tunisia experiences 'significant water scarcity' according to international standards. Note that we include in this analysis only the blue WF related to crop production, but this contributes $93 \%$ to the total blue WF in the country, so we underestimate water scarcity only slightly.

It is estimated that, at national scale, $73 \%$ of the blue WF of crop production relates to groundwater consumption, while $27 \%$ refers to surface water consumption. The blue WF that specifically relates to groundwater consumption represents $62 \%$ of the total renewable groundwater resources, which means that the country is facing severe water scarcity related to groundwater (Table 7).

At regional level, the highest overall water scarcity occurs in South Tunisia (severe scarcity of 78\%), followed by Central (significant scarcity of $32 \%$ ) and North (moderate water scarcity of $23 \%$ ). In terms of groundwater, 
all regions of the country experience severe water scarcity, with a scarcity of $47 \%$ in both North and Central and $123 \%$ in South Tunisia. The latter means that consumptive use of groundwater exceeds the renewable groundwater available in this region.

It is to be observed that the water scarcity figures presented here are calculated on an annual rather than a monthly basis. As noted by Hoekstra et al. (2012), this may lead to an underestimation of scarcity as experienced in the drier parts of the year, particularly because of the variability in available surface water resources within the year. For estimating groundwater scarcity, the annual approach will generally suffice because of the relatively long residence time and buffering capacity of groundwater systems. Groundwater scarcity figures are possibly underestimated, though, because return flows in groundwater-based irrigation are here assumed to return to the groundwater system from which abstraction took place, while part of the return flow may be surface runoff.

Table 7. Blue water footprint of crop production in the context of blue water availability.

\begin{tabular}{|c|c|c|c|c|c|c|c|c|c|c|}
\hline & \multirow{2}{*}{\multicolumn{3}{|c|}{ Blue water footprint $\left(\mathrm{Mm}^{3} / \mathrm{yr}\right)$}} & \multicolumn{5}{|c|}{ Blue water resources $\left(\mathrm{Mm}^{3} / \mathrm{yr}\right)$} & \multirow{2}{*}{\multicolumn{2}{|c|}{ Water scarcity (\%) ${ }^{\mathrm{e}}$}} \\
\hline & & & & \multicolumn{3}{|c|}{ Renewable blue water resources } & \multirow[b]{2}{*}{ Fossil $^{d}$} & \multirow[b]{2}{*}{ Total } & & \\
\hline & $\begin{array}{l}\text { Ground- } \\
\text { water }^{\mathrm{a}}\end{array}$ & $\begin{array}{l}\text { Surface } \\
\text { water }^{\text {a }}\end{array}$ & Total $^{\mathrm{b}}$ & $\begin{array}{l}\text { Ground- } \\
\text { water }^{d}\end{array}$ & $\begin{array}{l}\text { Surface } \\
\text { water }^{c}\end{array}$ & Total & & & $\begin{array}{l}\text { Ground- } \\
\text { water }\end{array}$ & Overall \\
\hline North & 320 & 330 & 650 & 680 & 2190 & 2870 & & 2870 & 47 & 23 \\
\hline Central & 270 & 20 & 290 & 570 & 320 & 890 & & 890 & 47 & 32 \\
\hline South & 380 & 10 & 390 & 310 & 190 & 500 & 610 & 1110 & 123 & 78 \\
\hline Total & 970 & 360 & 1330 & 1560 & 2700 & 4260 & 610 & 4870 & 62 & 31 \\
\hline
\end{tabular}

Sources:

a Based on WF data from Mekonnen and Hoekstra (2011b) and ratios of surface water withdrawal to groundwater withdrawal per region from Ministry of Agriculture (2005a,b). Using the surface/groundwater ratios for withdrawals for estimating the surface/groundwater ratios for blue WFs implicitly assumes that the fractions of return flow are similar for surface and groundwater abstractions.

${ }^{\mathrm{b}}$ Mekonnen and Hoekstra (2011b)

${ }^{c}$ Ministry of Environment (2009)

d Ministry of Agriculture (2005b)

e Own elaboration

\subsection{Economic water and land productivity at national level}

An analysis of water management in a Mediterranean country must have a focus on irrigated agriculture (Garrido et al., 2009). Although irrigated land accounts to only $7 \%$ of the total cultivated land in Tunisia (Chahed et al., 2008), it contributes to more than 35\% of the total production of the agricultural sector and accounts for more than $80 \%$ of the total water withdrawal in the country (Ministry of Environment, 2009).

Based on producer prices, Table 8 presents the economic water productivity (EWP) of main crops in Tunisia, for both rain-fed and irrigated agriculture. In the case of irrigated agriculture, we distinguish between green and blue EWP. For the listed crops, the average EWP in Tunisian crop production is around $0.32 \mathrm{US} \$ / \mathrm{m}^{3}$, which is slightly less than the figure found in a study for Spain by Garrido et al. (2009), who found an average value of around $0.25 € / \mathrm{m}^{3}$, which is equivalent to about $0.35 \mathrm{US} \$ / \mathrm{m}^{3}$. The average EWP in Tunisian rain-fed agriculture $\left(0.35 \mathrm{US} \$ / \mathrm{m}^{3}\right)$ was a bit higher than for irrigated agriculture $\left(0.32 \mathrm{US} \$ / \mathrm{m}^{3}\right)$. For several of the selected crops, 
EWP in rain-fed and irrigated production systems are found to be very similar. In the case of carrots and potatoes, however, total EWP is larger in irrigated agriculture than in rain-fed agriculture. For dates and tomatoes, we found the reverse.

In irrigated agriculture, the blue water applied is not always more productive than the green water. For carrots, potatoes and tomatoes the blue EWP in irrigated agriculture was found to be higher than the green EWP, but for dates and grapes the reverse was found. While most of the blue water in Tunisia is consumed in dates, grapes, olives and wheat production (Table 4), the blue EWP of these crops is low when compared to potatoes and tomatoes, which have the highest blue EWPs, with 0.97 and $1.13 \mathrm{US} \$ / \mathrm{m}^{3}$ respectively.

Table 8. Physical and economic water productivity of main crops in Tunisia at national level (1996-2005).

\begin{tabular}{|c|c|c|c|c|c|c|c|c|c|c|c|}
\hline \multirow[b]{2}{*}{ Crop } & \multicolumn{5}{|c|}{ Physical water productivity $\left(\mathrm{kg} / \mathrm{m}^{3}\right)^{\mathrm{a}}$} & \multirow[b]{2}{*}{$\begin{array}{l}\text { Producer } \\
\text { price } \\
{\text { (US } \$ / k g)^{b}}^{2}\end{array}$} & \multicolumn{5}{|c|}{ Economic water productivity $\left(\mathrm{US} \$ / \mathrm{m}^{3}\right)^{\mathrm{c}}$} \\
\hline & $\begin{array}{l}\text { Total } \\
\text { (green) } \\
\text { WP in } \\
\text { rain-fed } \\
\text { agric. }\end{array}$ & $\begin{array}{l}\text { Green } \\
\text { WP in } \\
\text { irrigated } \\
\text { agric. }\end{array}$ & $\begin{array}{l}\text { Blue WP } \\
\text { in } \\
\text { irrigated } \\
\text { agric. }\end{array}$ & $\begin{array}{l}\text { Total WP } \\
\text { in } \\
\text { irrigated } \\
\text { agric. }\end{array}$ & $\begin{array}{l}\text { Average } \\
\text { WP in } \\
\text { irrigated } \\
\text { \& rain-fed } \\
\text { agric. }\end{array}$ & & $\begin{array}{l}\text { Total } \\
\text { (green) } \\
\text { EWP in } \\
\text { rain-fed } \\
\text { agric. }\end{array}$ & $\begin{array}{l}\text { Green } \\
\text { EWP in } \\
\text { irrigated } \\
\text { agric. }\end{array}$ & $\begin{array}{l}\text { Blue } \\
\text { EWP in } \\
\text { irrigated } \\
\text { agric. }\end{array}$ & $\begin{array}{l}\text { Total } \\
\text { EWP in } \\
\text { irrigated } \\
\text { agric. }\end{array}$ & $\begin{array}{l}\text { Average } \\
\text { EWP in } \\
\text { irrigated } \\
\& \text { rain-fed } \\
\text { agric. }\end{array}$ \\
\hline Almonds & 0.05 & 0.05 & 0.05 & 0.05 & 0.05 & 1.70 & 0.09 & 0.09 & 0.09 & 0.09 & 0.09 \\
\hline Barley & 0.28 & 0.24 & 0.31 & 0.27 & 0.28 & 0.14 & 0.04 & 0.03 & 0.04 & 0.04 & 0.04 \\
\hline Carrots & 1.04 & 1.00 & 1.40 & 1.27 & 1.27 & 0.13 & 0.14 & 0.13 & 0.19 & 0.17 & 0.17 \\
\hline Dates & 0.40 & 0.61 & 0.11 & 0.23 & 0.23 & 1.01 & 0.40 & 0.62 & 0.11 & 0.23 & 0.23 \\
\hline Figs & 0.22 & 0.22 & 0.22 & 0.22 & 0.22 & 0.47 & 0.10 & 0.10 & 0.10 & 0.10 & 0.10 \\
\hline Grapes & - & 0.79 & 0.52 & 0.61 & 0.61 & 0.32 & - & 0.25 & 0.17 & 0.20 & 0.20 \\
\hline Olives & 0.11 & 0.11 & 0.11 & 0.11 & 0.11 & 0.32 & 0.03 & 0.03 & 0.03 & 0.03 & 0.03 \\
\hline Oranges & 1.69 & 1.68 & 1.68 & 1.68 & 1.68 & 0.34 & 0.58 & 0.58 & 0.58 & 0.58 & 0.58 \\
\hline Potatoes & 3.86 & 3.75 & 4.72 & 4.27 & 4.24 & 0.21 & 0.80 & 0.77 & 0.97 & 0.88 & 0.87 \\
\hline Tomatoes & 10.75 & 8.77 & 9.62 & 9.17 & 9.24 & 0.12 & 1.26 & 1.03 & 1.13 & 1.07 & 1.08 \\
\hline Wheat & 0.41 & 0.40 & 0.50 & 0.44 & 0.41 & 0.24 & 0.10 & 0.09 & 0.12 & 0.10 & 0.10 \\
\hline
\end{tabular}

Sources:

${ }^{a}$ Own elaboration based on data from Mekonnen and Hoekstra (2010)

${ }^{\mathrm{b}}$ FAOSTAT (FAO, 2009)

${ }^{\mathrm{c}}$ Own elaboration

Table 9 presents economic land productivity (ELP), again distinguishing between rain-fed and irrigated agriculture. In terms of total ELP, oranges, tomatoes and dates had the highest ELPs, with 4040, 3770 and 3080 US\$/ha respectively, while barley and olives had the lowest ELPs, with 130 and 170 US\$/ha respectively.

Economic land productivity is higher in irrigated agriculture than in rain-fed agriculture for all selected crops. Given the fact that, on average, economic water productivities in irrigated agriculture are not higher than in rainfed agriculture, one can conclude that irrigation water is generally not applied to increase water productivity $\left(\mathrm{US} \$ / \mathrm{m}^{3}\right.$ ) but rather to increase land productivity (US\$/ha). Enlarging the irrigated area for the listed crops will increase land productivity. But, since water is a limiting factor in production, it may be most beneficial to increase irrigated areas only for crops with high economic water productivity and for which the difference between ELP in rain-fed and irrigated agriculture is considerable, like for example potatoes. 
Dates and oranges had relatively low economic water productivities ( 0.23 and $0.58 \mathrm{US} \$ / \mathrm{m}^{3}$ respectively) as compared to potatoes $\left(0.87 \mathrm{US} \$ / \mathrm{m}^{3}\right.$ ) (see Table 8), but the ELPs for dates and oranges were higher (3080 and 4040 US\$/ha respectively) than the ELP for potatoes (2870 US\$/ha).

At a national level, the figures on economic water productivities (Table 8) provide little basis for understanding or explaining current cropping patterns. The figures on economic land productivities give a better basis for understanding, because various of the crops with large production volumes (especially tomatoes, potatoes, oranges and dates) have a relatively high ELP. The main exceptions are wheat, barley and olives, that have large production volumes but low ELP (and also low EWP).

Table 9. Yield and economic land productivity of main crops in Tunisia at national level (1996-2005).

\begin{tabular}{|c|c|c|c|c|c|c|c|c|c|c|c|}
\hline \multirow[b]{2}{*}{ Crop } & \multicolumn{5}{|c|}{ Yield (ton/ha) ${ }^{\mathrm{a}}$} & \multirow[b]{2}{*}{$\begin{array}{l}\text { Producer } \\
\text { price } \\
{\text { (US } \$ \text { ton })^{\mathrm{b}}}\end{array}$} & \multicolumn{5}{|c|}{ Economic land productivity (US $\$ / \mathrm{ha})^{\mathrm{c}}$} \\
\hline & $\begin{array}{c}\text { Total } \\
\text { (green) } \\
\text { yield in } \\
\text { rain-fed } \\
\text { agric. }\end{array}$ & $\begin{array}{l}\text { Green } \\
\text { yield in } \\
\text { irrigated } \\
\text { agric. }\end{array}$ & $\begin{array}{l}\text { Blue } \\
\text { yield in } \\
\text { irrigated } \\
\text { agric. }\end{array}$ & $\begin{array}{l}\text { Total } \\
\text { yield in } \\
\text { Irrigated } \\
\text { agric. }\end{array}$ & $\begin{array}{l}\text { Average } \\
\text { yield in } \\
\text { irrigated } \\
\& \text { rain- } \\
\text { fed agric. }\end{array}$ & & $\begin{array}{l}\text { ELP in } \\
\text { rain-fed } \\
\text { agric. }\end{array}$ & $\begin{array}{l}\text { Green- } \\
\text { water } \\
\text { based } \\
\text { ELP in } \\
\text { irrigated } \\
\text { agric. }\end{array}$ & $\begin{array}{l}\text { Blue- } \\
\text { water } \\
\text { based } \\
\text { ELP in } \\
\text { irrigated } \\
\text { agric. }\end{array}$ & $\begin{array}{l}\text { ELP in } \\
\text { irrigated } \\
\text { agric. }\end{array}$ & $\begin{array}{c}\text { Average } \\
\text { ELP in } \\
\text { irrigated } \\
\& \text { rain- } \\
\text { fed agric. }\end{array}$ \\
\hline Almonds & 0.23 & 0.22 & 0.26 & 0.48 & 0.25 & 1700 & 390 & 380 & 440 & 820 & 430 \\
\hline Barley & 0.90 & 0.66 & 0.61 & 1.27 & 0.91 & 140 & 130 & 90 & 90 & 180 & 130 \\
\hline Carrots & 2.41 & 1.98 & 6.00 & 7.98 & 7.69 & 130 & 320 & 270 & 800 & 1070 & 1030 \\
\hline Dates & 1.20 & 1.20 & 1.87 & 3.07 & 3.05 & 1010 & 1210 & 1210 & 1890 & 3100 & 3080 \\
\hline Figs & 0.98 & 0.93 & 0.78 & 1.72 & 1.53 & 470 & 460 & 442 & 370 & 810 & 720 \\
\hline Grapes & 3.24 & 2.01 & 2.59 & 4.60 & 4.60 & 320 & 1040 & 650 & 830 & 1480 & 1480 \\
\hline Olives & 0.51 & 0.49 & 0.41 & 0.90 & 0.53 & 320 & 160 & 150 & 130 & 280 & 170 \\
\hline Oranges & 7.60 & 7.14 & 5.99 & 13.13 & 11.75 & 340 & 2610 & 2460 & 2060 & 4520 & 4040 \\
\hline Potatoes & 6.74 & 5.84 & 9.30 & 15.14 & 13.95 & 210 & 1390 & 1200 & 1920 & 3120 & 2870 \\
\hline Tomatoes & 22.20 & 17.03 & 15.81 & 32.84 & 32.18 & 120 & 2600 & 1990 & 1850 & 3840 & 3770 \\
\hline Wheat & 1.54 & 1.23 & 0.99 & 2.21 & 1.58 & 240 & 370 & 290 & 240 & 530 & 370 \\
\hline
\end{tabular}

Sources:

${ }^{a}$ Own elaboration based on data from Mekonnen and Hoekstra (2010)

${ }^{\mathrm{b}}$ FAOSTAT (FAO, 2009)

${ }^{\mathrm{c}}$ Own elaboration

\subsection{Economic water and land productivity at sub-national level}

Tables 10 and 11 show economic water and land productivities, respectively, for the main crops at regional level. North and Central Tunisia have similar economic water productivities. South Tunisia has lower water productivities for the listed crops except for potatoes. North Tunisia has the highest economic land productivity (ELP) for all listed crops except for carrots, grapes and tomatoes. Central Tunisia has the highest ELP for carrots and tomatoes, while Central and South have similar ELP for grapes. South has the lowest ELP for all crops except for dates and grapes. 
Table 10. Physical and economic water productivity of main crops in Tunisia at regional level (1996-2005).

\begin{tabular}{|c|c|c|c|c|c|c|c|c|c|c|c|c|}
\hline & \multirow[b]{2}{*}{ Crop } & \multicolumn{5}{|c|}{ Physical water productivity $\left(\mathrm{m}^{3} / \mathrm{kg}\right)^{\mathrm{a}}$} & \multirow[b]{2}{*}{$\begin{array}{l}\text { Producer } \\
\text { price b } \\
\text { (US } \$ / \mathrm{kg} \text { ) }\end{array}$} & \multicolumn{5}{|c|}{ Economic water productivity $\left(\mathrm{US} \$ / \mathrm{m}^{3}\right)^{\mathrm{c}}$} \\
\hline & & $\begin{array}{l}\text { Total } \\
\text { (green) } \\
\text { WP in } \\
\text { rain-fed } \\
\text { agric. }\end{array}$ & $\begin{array}{c}\text { Green WP } \\
\text { in irrigated } \\
\text { agric. }\end{array}$ & $\begin{array}{l}\text { Blue WP in } \\
\text { irrigated } \\
\text { agric. }\end{array}$ & $\begin{array}{l}\text { Total WP } \\
\text { in } \\
\text { irrigated } \\
\text { agric. }\end{array}$ & $\begin{array}{l}\text { Average } \\
\text { WP in } \\
\text { irrigated } \\
\text { \& rain-fed } \\
\text { agric. }\end{array}$ & & $\begin{array}{l}\text { Total } \\
\text { (green) } \\
\text { EWP in } \\
\text { rain-fed } \\
\text { agric. }\end{array}$ & $\begin{array}{l}\text { Green EWP } \\
\text { in irrigated } \\
\text { agric. }\end{array}$ & $\begin{array}{l}\text { Blue EWP } \\
\text { in irrigated } \\
\text { agric. }\end{array}$ & $\begin{array}{l}\text { Total } \\
\text { EWP in } \\
\text { irrigated } \\
\text { agric. }\end{array}$ & $\begin{array}{c}\text { Average } \\
\text { EWP in } \\
\text { irrigated } \\
\& \text { rain-fed } \\
\text { agric. }\end{array}$ \\
\hline \multirow{11}{*}{$\begin{array}{l}\frac{5}{\bar{t}} \\
\frac{\mathrm{o}}{\mathrm{z}}\end{array}$} & Almonds & 0.05 & 0.05 & 0.05 & 0.05 & 0.05 & 1.70 & 0.09 & 0.09 & 0.09 & 0.09 & 0.09 \\
\hline & Barley & 0.28 & 0.23 & 0.36 & 0.28 & 0.28 & 0.14 & 0.04 & 0.03 & 0.05 & 0.04 & 0.04 \\
\hline & Carrots & 1.04 & 1.02 & 1.41 & 1.28 & 1.28 & 0.13 & 0.14 & 0.14 & 0.19 & 0.17 & 0.17 \\
\hline & Date & - & - & - & - & - & - & - & - & - & - & - \\
\hline & Figs & 0.22 & 0.22 & 0.22 & 0.22 & 0.22 & 0.47 & 0.10 & 0.10 & 0.10 & 0.10 & 0.10 \\
\hline & Grapes & - & 0.81 & 0.56 & 0.66 & 0.66 & 0.32 & - & 0.26 & 0.18 & 0.21 & 0.21 \\
\hline & Olives & 0.11 & 0.11 & 0.11 & 0.11 & 0.11 & 0.32 & 0.03 & 0.03 & 0.03 & 0.03 & 0.03 \\
\hline & Oranges & 1.69 & 1.68 & 1.68 & 1.68 & 1.68 & 0.34 & 0.58 & 0.58 & 0.58 & 0.58 & 0.58 \\
\hline & Potatoes & 3.86 & 3.75 & 4.71 & 4.28 & 4.25 & 0.21 & 0.80 & 0.77 & 0.97 & 0.88 & 0.88 \\
\hline & Tomatoes & 10.72 & 8.84 & 9.67 & 9.21 & 9.29 & 0.12 & 1.25 & 1.03 & 1.13 & 1.08 & 1.09 \\
\hline & Wheat & 0.41 & 0.40 & 0.51 & 0.44 & 0.41 & 0.24 & 0.10 & 0.10 & 0.12 & 0.10 & 0.10 \\
\hline \multirow{11}{*}{ 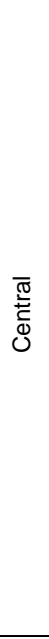 } & Almonds & 0.05 & 0.05 & 0.05 & 0.05 & 0.05 & 1.70 & 0.08 & 0.09 & 0.09 & 0.09 & 0.09 \\
\hline & Barley & 0.26 & 0.24 & 0.31 & 0.27 & 0.26 & 0.14 & 0.04 & 0.03 & 0.04 & 0.04 & 0.04 \\
\hline & Carrots & 1.00 & 0.94 & 1.36 & 1.24 & 1.24 & 0.13 & 0.13 & 0.13 & 0.18 & 0.17 & 0.17 \\
\hline & Dates & - & - & - & - & - & - & - & - & - & - & - \\
\hline & Figs & 0.21 & 0.22 & 0.22 & 0.22 & 0.22 & 0.47 & 0.10 & 0.10 & 0.10 & 0.10 & 0.10 \\
\hline & Grapes & - & 0.77 & 0.52 & 0.61 & 0.61 & 0.32 & - & 0.25 & 0.17 & 0.19 & 0.19 \\
\hline & Olives & 0.11 & 0.11 & 0.11 & 0.11 & 0.11 & 0.32 & 0.03 & 0.03 & 0.03 & 0.03 & 0.03 \\
\hline & Oranges & 1.67 & 1.68 & 1.68 & 1.68 & 1.68 & 0.34 & 0.58 & 0.58 & 0.58 & 0.58 & 0.58 \\
\hline & Potatoes & 3.86 & 3.57 & 4.69 & 4.28 & 4.26 & 0.21 & 0.80 & 0.73 & 0.97 & 0.88 & 0.88 \\
\hline & Tomatoes & 10.98 & 8.70 & 9.62 & 9.21 & 9.22 & 0.12 & 1.28 & 1.02 & 1.13 & 1.08 & 1.08 \\
\hline & Wheat & 0.38 & 0.38 & 0.50 & 0.43 & 0.39 & 0.24 & 0.09 & 0.09 & 0.12 & 0.10 & 0.09 \\
\hline \multirow{11}{*}{$\begin{array}{l}\bar{F} \\
\text { 志 } \\
\text { 心 }\end{array}$} & Almonds & 0.04 & 0.04 & 0.04 & 0.04 & 0.04 & 1.70 & 0.07 & 0.07 & 0.07 & 0.07 & 0.07 \\
\hline & Barley & 0.21 & 0.43 & 0.12 & 0.21 & 0.21 & 0.14 & 0.03 & 0.06 & 0.02 & 0.03 & 0.03 \\
\hline & Carrots & 1.02 & 1.03 & 1.43 & 1.30 & 1.29 & 0.13 & 0.14 & 0.14 & 0.19 & 0.17 & 0.17 \\
\hline & Dates & 0.40 & 0.61 & 0.11 & 0.23 & 0.23 & 1.01 & 0.40 & 0.62 & 0.11 & 0.23 & 0.23 \\
\hline & Figs & 0.17 & 0.17 & 0.17 & 0.17 & 0.17 & 0.47 & 0.08 & 0.08 & 0.08 & 0.08 & 0.08 \\
\hline & Grapes & - & 1.14 & 0.39 & 0.54 & - & 0.32 & - & 0.37 & 0.13 & 0.17 & 0.17 \\
\hline & Olives & 0.09 & 0.09 & 0.09 & 0.09 & 0.09 & 0.32 & 0.03 & 0.03 & 0.03 & 0.03 & 0.03 \\
\hline & Oranges & 1.45 & 1.39 & 1.39 & 1.39 & 1.40 & 0.34 & 0.50 & 0.48 & 0.48 & 0.48 & 0.48 \\
\hline & Potatoes & 3.96 & 3.74 & 4.86 & 4.42 & 4.34 & 0.21 & 0.81 & 0.77 & 1.00 & 0.91 & 0.89 \\
\hline & Tomatoes & 8.62 & 6.00 & 7.59 & 7.23 & 8.61 & 0.12 & 1.01 & 0.70 & 0.89 & 0.85 & 1.01 \\
\hline & Wheat & 0.19 & 0.20 & 0.39 & 0.34 & 0.28 & 0.24 & 0.04 & 0.05 & 0.09 & 0.08 & 0.07 \\
\hline
\end{tabular}

Sources:

${ }^{a}$ Own elaboration based on data from Mekonnen and Hoekstra (2010)

${ }^{b}$ FAOSTAT (FAO, 2009)

${ }^{\mathrm{c}}$ Own elaboration 
Table 11. Yield and economic land productivity of main crops in Tunisia at regional level (1996-2005).

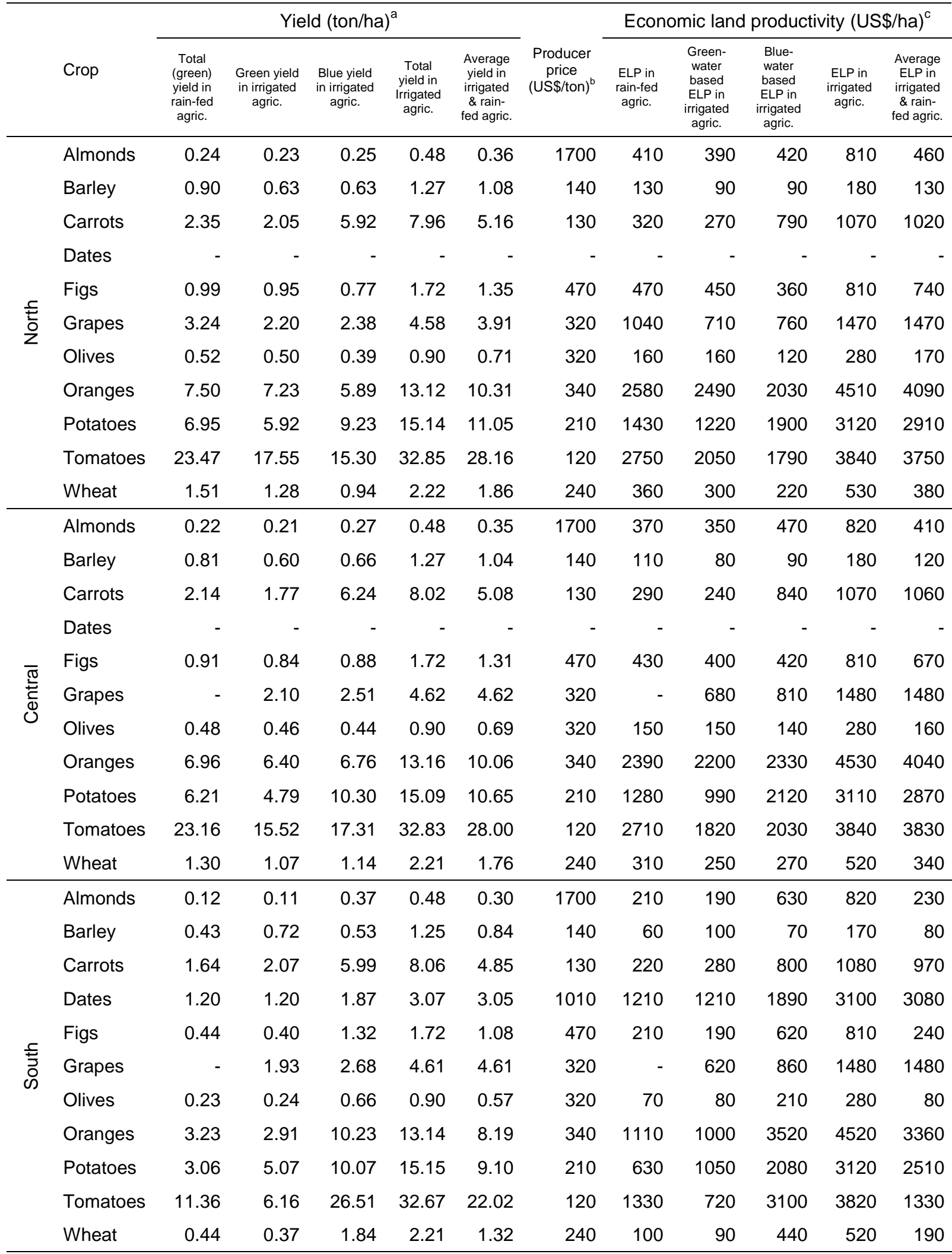

Sources:

${ }^{a}$ Own elaboration based on data from Mekonnen \& Hoekstra (2010)

${ }^{\mathrm{b}}$ FAOSTAT (FAO, 2009)

${ }^{\mathrm{C}}$ Own elaboration 
When comparing rain-fed and irrigated agriculture, we find that the ELP of irrigated lands is much higher than the ELP of rain-fed lands for all listed crops. In South Tunisia, which is much drier than North and Central, the blue-water based ELP in irrigated agriculture is higher for all crops than in North and Central, which illustrates the greater importance of irrigation water to yields in the South.

The same conclusion that we have drawn at the national level is valid at regional level: enlarging the irrigation areas will generally increase ELPs, particularly in the South. But primarily in the South, water availability is the key limiting factor in production, not land availability, so that optimizing EWP will be more advisable than optimizing ELP.

For South Tunisia it is especially attractive to grow dates, because the climate and growing conditions are very suitable for this crop; dates are not grown in North and Central. The ELP for dates is high as well, but the EWP is not. From the perspective of a most economic use of scarce freshwater resources in South, it is more attractive to grow potatoes, tomatoes and oranges than to grow dates.

The study of economic water and land productivity has a number of limitations that are mostly due to a lack of data. First, we assumed the producer price of crops to be the same for the Tunisian regions, where differences can somewhat affect the results at regional level. Second, we did not distinguish between prices for rain-fed and irrigated crops. Irrigated crops may have a higher price due to better control of the production process, which would translate into a higher economic water and land productivity in irrigated agriculture. Third, we calculate economic water and land productivity by multiplying physical productivity and price, while it is better to look at the value added per unit of production. Finally, we assumed full irrigation in irrigated agriculture, while in reality irrigation may (deliberately or involuntarily) be limited.

\subsection{Virtual water flows related to trade in agricultural and industrial products}

\subsubsection{Tunisian virtual water import}

The total gross virtual water import in the period $1996-2005$ was $8100 \mathrm{Mm}^{3} / \mathrm{yr}$ (71\% blue, $18 \%$ green and $11 \%$ grey, Table 12). The largest contribution (94\%) related to import of crop products. Imports of animal products and industrial products contributed with $2 \%$ and $4 \%$ respectively. The economic value of imports was 10330 million US $\$ / y$ r, of which $80 \%$ related to import of industrial products, $18 \%$ to import of crop products and $2 \%$ to import of animal products. The average cost of imported commodities per unit of virtual water imported was $1.28 \mathrm{US} \$ \mathrm{~m}^{3}$.

Crops responsible for relatively large virtual water imports are cotton, wheat, soybean, maize, sugar and barley. The import of cotton products (mainly from France, Belgium and Italy) and wheat (mainly from Canada, France and Spain) were responsible for 2200 and $1850 \mathrm{Mm}^{3} / \mathrm{yr}$, respectively (Table 13), which together represents 53\% of the total virtual water imported. The total economic value of crop products imported by Tunisia was 1840 
million US\$/yr. About $51 \%$ of the total cost is related to import of cotton products and $16 \%$ to import of sugar products. The average cost of imported crops per unit of virtual water imported was $0.24 \mathrm{US} \$ / \mathrm{m}^{3}$.

About $49 \%$ of the crop-related virtual water imports of Tunisia comes from Europe (Figure 5), mainly from France, Italy, Germany and Belgium; 17\% comes from Latin America, 13\% from Asia, 12\% from North America and $1 \%$ from Oceania. For animal products and industrial products, the biggest part of the virtual water imported, about $68 \%$ comes from Europe, mainly from France and Germany for animal products and from France and Italy for industrial products. Figure 5 summarizes the results per continent, where Latin America includes Mexico, and Europe includes Turkey and the Russian Federation.

Table 12. Tunisia's virtual water import and economic value of imports. Period: 1996-2005.

\begin{tabular}{lcccc}
\hline & $\begin{array}{c}\text { Related to crop } \\
\text { products }\end{array}$ & $\begin{array}{c}\text { Related to animal } \\
\text { products }\end{array}$ & $\begin{array}{c}\text { Related to } \\
\text { industrial products }\end{array}$ & $\begin{array}{c}\text { Total virtual water } \\
\text { imported }\end{array}$ \\
\hline Green $\left(\mathrm{Mm}^{3} / \mathrm{yr}\right)^{\mathrm{a}}$ & 5610 & 140 & - & 5750 \\
Blue $\left(\mathrm{Mm}^{3} / \mathrm{yr}\right)^{\mathrm{a}}$ & 1400 & 20 & 30 & 1450 \\
Grey $\left(\mathrm{Mm}^{3} / \mathrm{yr}\right)^{\mathrm{a}}$ & 600 & 10 & 280 & 890 \\
Total $\left(\mathrm{Mm}^{3} / \mathrm{yr}\right)^{\mathrm{a}}$ & 7610 & 170 & 310 & 8100 \\
\hline $\begin{array}{l}\text { Economic value of imports } \\
(\text { million US } \$ / \mathrm{yr})^{\mathrm{b}}\end{array}$ & 1840 & 150 & 8330 & 10330 \\
\hline $\begin{array}{l}\text { Value per unit of imported } \\
\text { virtual water }\left(\mathrm{US} \$ \mathrm{~m}^{3}\right)^{\mathrm{c}}\end{array}$ & 0.24 & 0.85 & 27.00 & 1.28 \\
\hline
\end{tabular}

Sources:

a Hoekstra and Mekonnen (2012)

b ITC (2007)

${ }^{\mathrm{c}}$ Own elaboration

Table 13. Imported crops with a large volume of virtual water. Period: 1996-2005.

\begin{tabular}{|c|c|c|c|c|c|c|c|}
\hline \multirow{2}{*}{ Crop } & \multirow{2}{*}{$\begin{array}{l}\% \text { of the total } \\
\text { virtual water } \\
\text { imported }^{a}\end{array}$} & \multicolumn{4}{|c|}{ Virtual water import $\left(\mathrm{Mm}^{3} / \mathrm{yr}\right)^{\mathrm{b}}$} & \multirow{2}{*}{$\begin{array}{c}\text { Economic } \\
\text { value }(\text { million } \\
\text { US } \$ / y r)^{\mathrm{c}}\end{array}$} & \multirow{2}{*}{$\begin{array}{l}\text { Value per unit of } \\
\text { imported water } \\
(\cup S \$ / \mathrm{m} 3)^{a}\end{array}$} \\
\hline & & Green & Blue & Grey & Total & & \\
\hline Cotton & $29 \%$ & 1250 & 760 & 200 & 2210 & 940 & 0.40 \\
\hline Wheat & $24 \%$ & 1650 & 60 & 150 & 1850 & 200 & 0.10 \\
\hline Soybeans & $15 \%$ & 840 & 280 & 20 & 1140 & 140 & 0.10 \\
\hline Maize & $8 \%$ & 500 & 40 & 100 & 640 & 100 & 0.20 \\
\hline Sugar & $7 \%$ & 380 & 110 & 30 & 520 & 290 & 0.60 \\
\hline Barley & $4 \%$ & 300 & 10 & 30 & 340 & 40 & 0.10 \\
\hline Coffee & $2 \%$ & 180 & 1 & 2 & 190 & 10 & 0.10 \\
\hline Other & $11 \%$ & 520 & 140 & 70 & 730 & 130 & 0.20 \\
\hline Total & $100 \%$ & 5610 & 1400 & 600 & 7610 & 1840 & 0.25 \\
\hline
\end{tabular}

Sources:

a Own elaboration

${ }^{\mathrm{b}}$ Hoekstra and Mekonnen (2012)

c ITC (2007) 


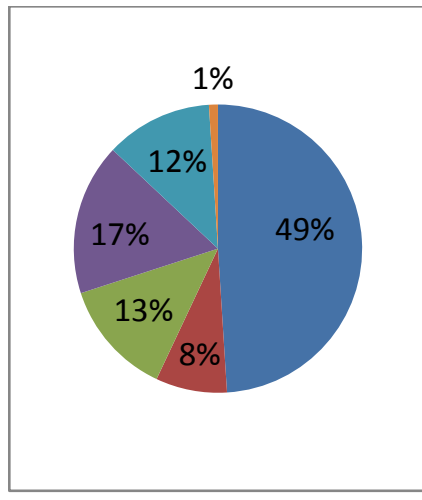

Virtual water import related to crop products

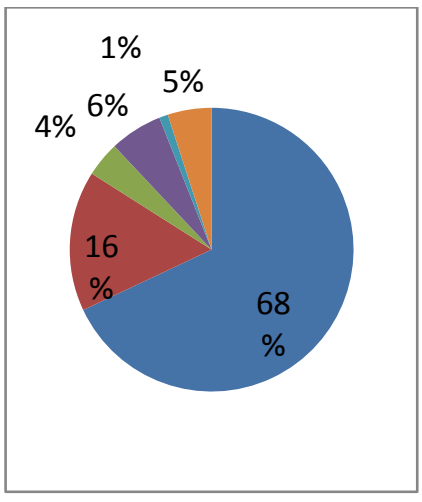

Virtual water import related to animal products

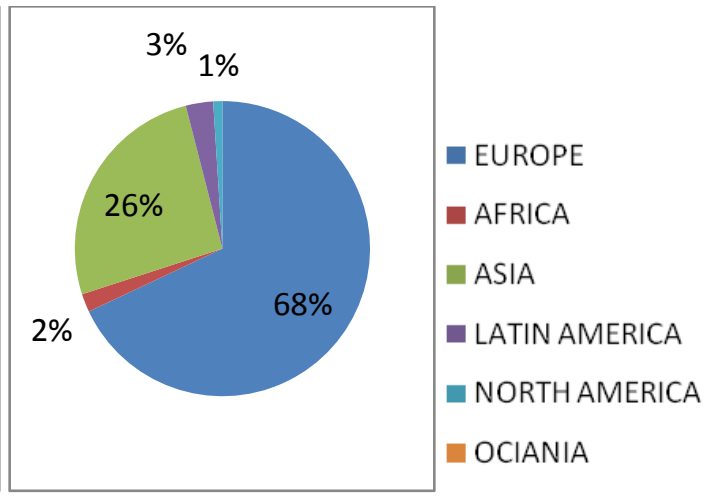

Virtual water import related to industrial products

Figure 5. Virtual water import of Tunisia specified by continent for the period 1996-2005. Source: based on data from Hoekstra and Mekonnen (2012).

\subsubsection{Tunisian virtual water export}

The total gross virtual water export in the period 1996-2005 was $9760 \mathrm{Mm}^{3} / \mathrm{yr}(88 \%$ blue, $5 \%$ green and $7 \%$ grey, Table 14). The export of crop products contributed most (95\%) to the total virtual water export, followed by export of animal products (3\%) and export of industrial products (2\%). The export value was 9760 million US\$yr, of which $67 \%$ related to export of industrial products, $32 \%$ to export of crop products and $1 \%$ to export of animal products. Thus, Tunisia generated a foreign exchange of about $1.00 \mathrm{US} \$ / \mathrm{m}^{3}$ on average.

Olive oil and cotton products were the main crop products, contributing $68 \%$ and $26 \%$ respectively to Tunisia's crop-related virtual water export (Table 15). The virtual water export related to the two crops was estimated at 6360 and $2380 \mathrm{Mm}^{3} / \mathrm{yr}$, respectively. About $73 \%$ of the total green water exported was related to export of olive oil $\left(6110 \mathrm{Mm}^{3} / \mathrm{yr}\right)$. The economic value of crop export was 3120 million US\$/yr, whereby cotton export represented $89 \%$ of the total export earnings. The average earning per unit of crop-related virtual water export was $0.35 \mathrm{US} \$ / \mathrm{m}^{3}$. The export of cotton products gives the highest earning per drop of water $\left(1.20 \mathrm{US} \$ / \mathrm{m}^{3}\right)$, while export of wheat generates the lowest earning $\left(0.02 \mathrm{US} \$ / \mathrm{m}^{3}\right)$. In terms of blue water, olive oil generates the highest earning per drop of water.

Tunisia is a net virtual water exporter related to cotton trade; the water footprint of exported cotton (2380 $\left.\mathrm{Mm}^{3} / \mathrm{yr}\right)$ exceeds the water footprint of imported cotton $\left(2210 \mathrm{Mm}^{3} / \mathrm{yr}\right)$. The earning per unit of water in the case of cotton export $\left(1.20 \mathrm{US} \$ / \mathrm{m}^{3}\right)$ is bigger than the cost per unit of water in the case of cotton import $(0.40$ US $\$ \mathrm{~m}^{3}$ ), which can be explained by the fact that most of the cotton exported from Tunisia is a re-export of the imported cotton after processing to textile, yielding a value added.

On the other hand, Tunisia is a net virtual water importer related to trade in wheat. Gross virtual water import related to wheat import is $1850 \mathrm{Mm}^{3} / \mathrm{yr}$, and gross virtual water export related to wheat export amounts to 190 $\mathrm{Mm}^{3} / \mathrm{yr}$. The export makes little sense, since the earning per unit of water for wheat exports $\left(0.02 \mathrm{US} \$ / \mathrm{m}^{3}\right)$ is 
very low compared to other crops and also much lower than the cost per unit of water for imported wheat $(0.10$ $\left.\mathrm{US} \$ / \mathrm{m}^{3}\right)$.

About $85 \%$ of the crop-related virtual water export goes to Europe (Figure 6), mainly to Italy, Spain and France; $6 \%$ goes to Latin America, 4\% to North America, 4\% to Africa, and 1\% to Asia. For animal products the biggest part goes to Africa (86\%), mainly Libya, while for industrial products the biggest part is exported to Europe $(88 \%)$, mainly to France, Italy and Germany.

Table 14. Tunisia's virtual water export and economic value of exports. Period: 1996-2005.

\begin{tabular}{lcccc}
\hline & $\begin{array}{c}\text { Related to crop } \\
\text { products }\end{array}$ & $\begin{array}{c}\text { Related to animal } \\
\text { products }\end{array}$ & $\begin{array}{c}\text { Related to industrial } \\
\text { products }\end{array}$ & $\begin{array}{c}\text { Total virtual water } \\
\text { exported }\end{array}$ \\
\hline Green $^{\mathrm{a}}\left(\mathrm{Mm}^{3} / \mathrm{yr}\right)$ & 8320 & 260 & - & 8580 \\
Blue $^{\mathrm{a}}\left(\mathrm{Mm}^{3} / \mathrm{yr}\right)$ & 400 & 40 & 10 & 460 \\
Grey $^{\mathrm{a}}\left(\mathrm{Mm}^{3} / \mathrm{yr}\right)$ & 570 & 20 & 130 & 730 \\
Total $^{(\mathrm{Mm} / \mathrm{yr})}$ & 9300 & 320 & 150 & 9760 \\
\hline $\begin{array}{l}\text { Economic value of exports } \\
\text { (million US } \$ / \mathrm{yr})\end{array}$ & 3120 & 20 & 6620 & 9760 \\
\hline $\begin{array}{l}\text { Value per unit of exported } \\
\text { water }\left(\mathrm{US} \$ \mathrm{~m}^{3}\right)^{\mathrm{c}}\end{array}$ & 0.35 & 0.05 & 50 & 1.00 \\
\hline
\end{tabular}

Sources:

${ }^{a}$ Hoekstra and Mekonnen (2012)

b ITC (2007)

${ }^{\mathrm{C}}$ Own elaboration

Table 15. Exported crops with a large volume of virtual water. Period: 1996-2005.

\begin{tabular}{|c|c|c|c|c|c|c|c|c|c|}
\hline \multirow[t]{2}{*}{ Crop } & \multirow{2}{*}{$\begin{array}{c}\% \text { of the total } \\
\text { virtual water } \\
\text { exported }^{\mathrm{a}}\end{array}$} & \multicolumn{4}{|c|}{ Virtual water export $\left(\mathrm{Mm}^{3} / \mathrm{yr}\right)^{\mathrm{b}}$} & \multirow{2}{*}{$\begin{array}{c}\text { Economic } \\
\text { value (million } \\
\text { US } \$ / y r)^{\mathrm{c}}\end{array}$} & \multicolumn{3}{|c|}{$\begin{array}{l}\text { Value per unit of exported } \\
\text { water }\left(\mathrm{US} \$ / \mathrm{m}^{3}\right)^{\mathrm{a}}\end{array}$} \\
\hline & & Green & Blue & Grey & Total & & Green & Blue & Total \\
\hline Olive oil & $68 \%$ & 6110 & 230 & 30 & 6360 & 230 & 0.03 & 1.00 & 0.04 \\
\hline Cotton & $26 \%$ & 1860 & 0 & 520 & 2380 & 2780 & 1.50 & - & 1.20 \\
\hline Wheat & $2 \%$ & 170 & 10 & 10 & 190 & 4 & 0.02 & 0.70 & 0.02 \\
\hline Dates & $2 \%$ & 40 & 120 & 3 & 160 & 70 & 1.80 & 0.60 & 0.40 \\
\hline Other & $2 \%$ & 140 & 60 & 20 & 220 & 50 & 0.30 & 0.90 & 0.20 \\
\hline Total & $100 \%$ & 8320 & 400 & 570 & 9300 & 3120 & 0.40 & 0.90 & 0.30 \\
\hline
\end{tabular}

Sources:

${ }^{a}$ Own elaboration

${ }^{\mathrm{b}}$ Hoekstra and Mekonnen (2012)

c ITC (2007) 


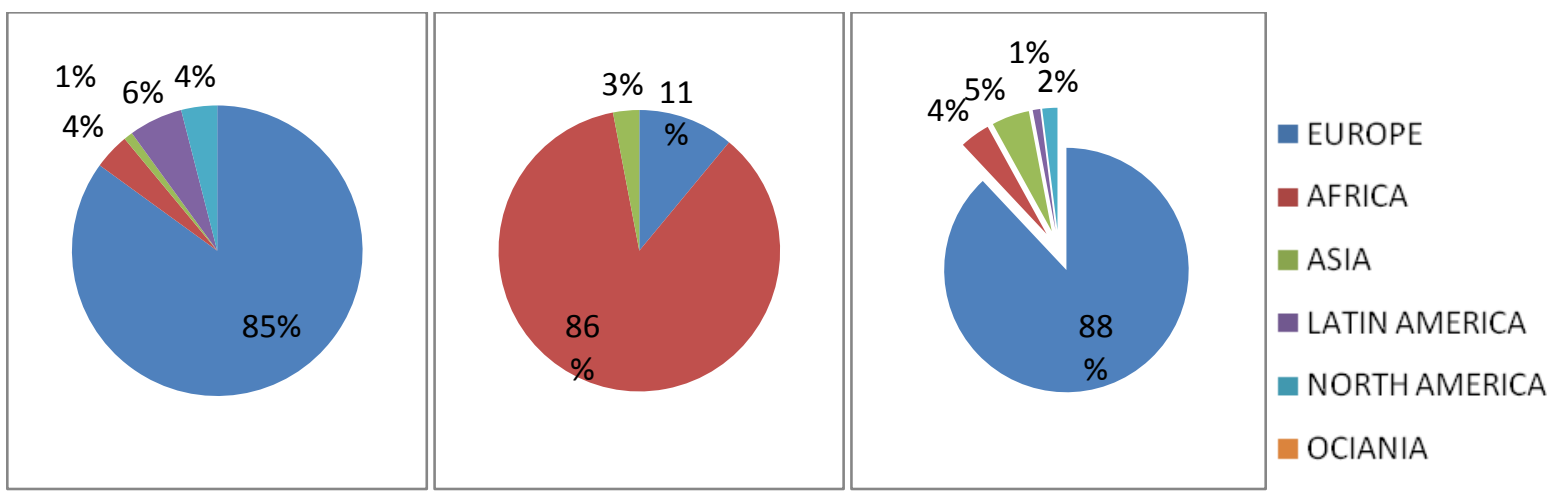
$\begin{array}{ccc}\begin{array}{c}\text { Virtual water export related } \\ \text { to crop products }\end{array} & \begin{array}{c}\text { Virtual water export related } \\ \text { to animal products }\end{array} & \begin{array}{c}\text { Virtual water export related } \\ \text { to industrial products }\end{array}\end{array}$

Figure 6. Virtual water export from Tunisia specified by continent for the period 1996-2005. Source: based on data from Mekonnen and Hoekstra (2010a, 2010b).

\subsection{Water saving through virtual water trade}

Even though Tunisia had a net virtual water export of $1660 \mathrm{Mm}^{3} / \mathrm{yr}$ in the period 1996-2005, the country saved water through trade. This can be understood as follows. Tunisia had a total gross virtual water export of 9760 $\mathrm{Mm}^{3} / \mathrm{yr}$. This is the volume of water that the country 'lost' (between brackets, because foreign currency came in return of course). The country had a gross virtual water import of $8100 \mathrm{Mm}^{3} / \mathrm{yr}$. This is the volume of water used in other countries to produce commodities for Tunisian consumption. If Tunisia had produced the imported commodities domestically, however, it would have taken more water, namely $10700 \mathrm{Mm}^{3} / \mathrm{yr}$, due to lower water productivities in Tunisia compared to countries from where Tunisia received its imports. So, whereas the country 'lost' $9760 \mathrm{Mm}^{3} / \mathrm{yr}$, it 'saved' $10700 \mathrm{Mm}^{3} / \mathrm{yr}$. The resultant net water saving was $940 \mathrm{Mm}^{3} / \mathrm{yr}(62 \%$ green, $3 \%$ blue and $35 \%$ grey). Trade in crop products was responsible for the largest part of the total water saving $(58 \%)$, followed by trade in animal products $(38 \%)$ and industrial products $(4 \%)$. Table 16 shows the contributions of the different product groups to the total water savings.

Regarding blue water, only trade in animal and industrial products resulted in net blue water saving (20 and 4 $\mathrm{Mm}^{3} / \mathrm{yr}$, respectively). Trade in crop products resulted in a net blue water loss of $1 \mathrm{Mm}^{3} / \mathrm{yr}$. Concerning green water, the largest amount of green water saved $\left(320 \mathrm{Mm}^{3} / \mathrm{yr}\right)$ related to trade in animal products.

Table 16. Water saving in Tunisia through trade $\left(\mathrm{Mm}^{3} / \mathrm{yr}\right)$ in the period 1996-2005.

\begin{tabular}{lcccr}
\hline & Green & Blue & Grey & Total \\
\hline $\begin{array}{l}\text { Related to trade in } \\
\text { crop products }\end{array}$ & 270 & -1 & 280 & 540 \\
$\begin{array}{l}\text { Related to trade in } \\
\text { animal products }\end{array}$ & 320 & 20 & 10 & 360 \\
$\begin{array}{l}\text { Related to trade in } \\
\text { industrial products }\end{array}$ & - & 4 & 40 & 40 \\
\hline Total & 590 & 30 & 330 & 940 \\
\hline
\end{tabular}

Source: Mekonnen and Hoekstra (2011a). 


\subsection{The water footprint of consumption}

The water footprint (WF) of Tunisian consumption was $2200 \mathrm{~m}^{3} / \mathrm{yr}$ per capita over the period 1996-2005, which is about $60 \%$ larger than the world average of $1390 \mathrm{~m}^{3} / \mathrm{yr}$ (Hoekstra and Mekonnen, 2012). Consumption of agricultural products largely determines the total WF related to consumption, contributing $98 \%$ to the total WF. Consumption of industrial products and domestic water supply contribute only $1 \%$ each.

In total terms, the WF of Tunisian consumption was $21 \mathrm{Gm}^{3} / \mathrm{yr}(81 \%$ green, $12 \%$ blue and $7 \%$ grey). Wheat was the product with the single largest contribution, with $480 \mathrm{~m}^{3} / \mathrm{yr}$ per capita ( $91 \%$ green, $3 \%$ blue, $6 \%$ grey). Table 17 shows the top-five of products with the largest contribution to the WF of Tunisian consumption. The external component of the WF consumption was $6810 \mathrm{Mm}^{3} / \mathrm{yr}$ (70\% green, $19 \%$ blue, $11 \%$ grey), which represents $32 \%$ of the total WF, while the internal component was $14220 \mathrm{Mm}^{3} / \mathrm{yr}(87 \%$ green, $8 \%$ blue, $5 \%$ grey) (Figure 7). In terms of its water needs, Tunisia has a particular dependency on Europe; the largest part of the country's virtual water imports come from Italy, France and Germany.

Table 17. Top-five of products with the largest contribution to the water footprint of Tunisian consumption.

\begin{tabular}{lcccc}
\hline \multirow{2}{*}{ Product } & \multicolumn{4}{c}{ Water footprint $\left(\mathrm{m}^{3} / \mathrm{yr} / \mathrm{capita}\right)$} \\
\cline { 2 - 5 } Wheat & Green & Blue & Grey & Total \\
Bovine meat & 440 & 10 & 30 & 480 \\
Olive oil & 280 & 20 & 10 & 320 \\
Meat, other & 210 & 10 & 0 & 220 \\
Milk and its products, excluding butter & 140 & 60 & 10 & 200 \\
\hline
\end{tabular}

Source: Mekonnen and Hoekstra (2011a).

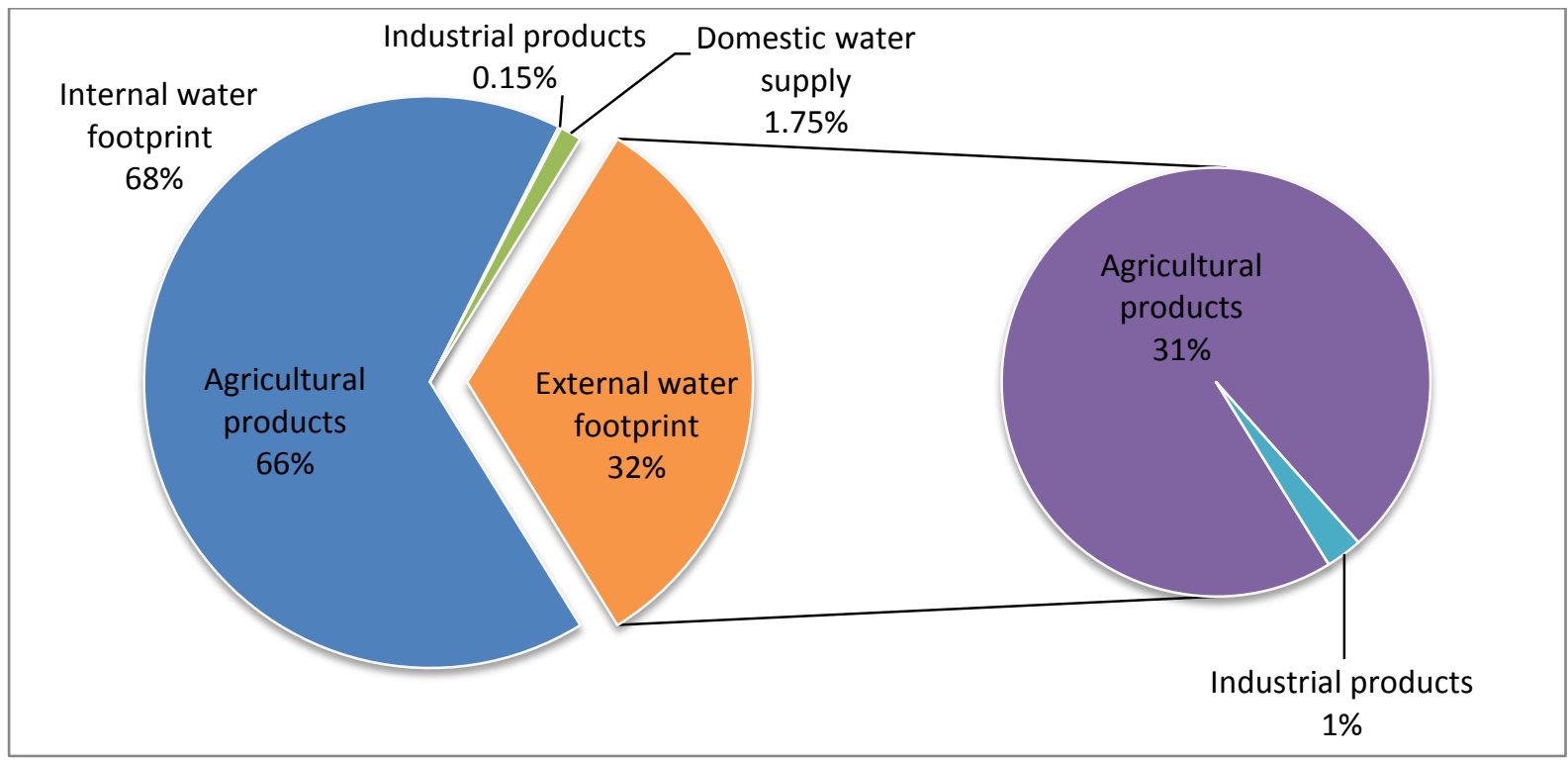

Figure 7. Composition of the water footprint of Tunisian consumption in the period 1996-2005. Source: based on data from Mekonnen and Hoekstra (2011a). 


\section{Conclusions}

The water footprint (WF) of Tunisian production was $19 \mathrm{Gm}^{3} / \mathrm{yr}$ in the period 1996-2005. Green water had the biggest contribution (89\%), but there are regional differences. Crops in South generally have a larger total WF and larger blue water fraction than in Central and North Tunisia, caused by differences in climate. South is an arid region, which explains why the WF in this region is dominantly blue.

The country suffers significant water scarcity, with a national blue WF of crop production amounting to $31 \%$ of the country's renewable blue water resources. South Tunisia experiences severe water scarcity, Central Tunisia significant scarcity and North Tunisia moderate scarcity. For groundwater in particular, all three regions experience severe water scarcity, with the worst situation in South, where the blue WF resting on groundwater exceeds renewable groundwater resources by an estimated $23 \%$.

The overview of water productivities of different crops shows that $91 \%$ of the total blue WF of crop production in the country relates to crops produced at blue water productivities of less than $0.20 \mathrm{US} \$ / \mathrm{m}^{3}$. Only tomatoes, potatoes and oranges show larger blue water productivities. The smallest blue water productivity is found for olives $\left(0.03 \mathrm{US} \$ / \mathrm{m}^{3}\right)$, one of the major export products of the country.

Among the major crops grown in Tunisia, oranges, tomatoes and potatoes have relatively large economic water and land productivities. The same, but to a lesser extent, is true for dates, which are grown in South only. Relatively low economic water and land productivities are found for wheat, barley, almonds, olives and figs. It is further found that irrigation generally increases economic land productivity (US $\$ /$ ha), but not water productivity $\left(\mathrm{US} \$ / \mathrm{m}^{3}\right)$. The contribution of blue water to economic land productivity is largest in the dry South.

Relatively large virtual water imports relate to imports of cotton, sugar and cereal crops, mainly from Europe. Olive oil and cotton are the crop products contributing most to virtual water export. The average cost of imported crops per unit of virtual water imported was $0.24 \mathrm{US} \$ / \mathrm{m}^{3}$, while the earning of exported crops per unit of virtual water exported was $0.34 \mathrm{US} \$ / \mathrm{m}^{3}$. Gross virtual water export from Tunisia exceeds gross virtual water import, but at least the benefit per drop of water used for making export products is larger than the cost per drop of water in import products.

Tunisia is not water self-sufficient with $32 \%$ of its total WF of consumption outside its borders, mostly in Europe. Given the water scarcity in the country it is unlikely that the country will be able to decrease its dependency on external water resources.

The results of this study show that the scarce Tunisian water resources have mainly been allocated to uses with low economic productivity; this could be the result of the agricultural policy followed by the Tunisian government. Over the last forty years, Tunisia's agricultural policy focussed on ensuring food security. by encouraging the production of staple crops such as wheat, barley and olive oil and livestock products such as milk and meat. This policy intended to ensure a lower price for those products than the international market price 
(Ministry of Agriculture, 2002). However, in the last few years, Tunisian authorities have started to re-think the country's agricultural policy and integrate it with the management of its scarce water resources. By the end of 1999, Tunisia signed a free trade agreement with the EU, encouraging imports in the agricultural sector (Ministry of Agriculture, 2002). Where market conditions exist and staple foods may be supplied from other sources, farmers can be encouraged to shift from low-value to high-value crops and increase the economic productivity of water in agriculture (FAO, 2012). 


\section{References}

Allan, J.A. (1993) Fortunately there are substitutes for water otherwise our hydro-political futures would be impossible, In: ODA, Priorities for water resources allocation and management, ODA, London, pp. 1326.

Chahed, J., Hamdane, A. and Besbes, M. (2008) A comprehensive water balance of Tunisia: blue water, green water and virtual water, Water International, 33(4): 415-424.

Chahed, J., Besbes, M. and Hamdane, A. (2011) Alleviating water scarcity by optimizing "Green VirtualWater": the case of Tunisia, In: Hoekstra, A.Y., Aldaya, M.M. and Avril, B. (eds.) Proceedings of the ESF Strategic Workshop on accounting for water scarcity and pollution in the rules of international trade, Amsterdam, 25-26 November 2010, Value of Water Research Report Series No. 54, UNESCO-IHE, Delft, the Netherlands, pp. 99-113.

Chapagain, A.K. and Hoekstra, A.Y. (2004) Water footprints of nations, Value of Water Research Report Series No.16, UNESCO-IHE. Delft, The Netherlands.

Chelbi, I. Kaabi, B. Béjaoui, M. Derbali, M. and Zhioua E. (2009) Spatial Correlation Between PhlebotomuspapatasiScopoli (Diptera: Psychodidae) and Incidence of Zoonotic Cutaneous Leishmaniasis in Tunisia, Journal of Medical Entomology 46(2): 400-402.

Cook, S., Gichuki, F. and Turral, H. (2006) Water productivity: estimation at plot, farm and basin scale. Basin Focal Project Working Paper No. 2, GGIAR Challenge Program on Water and Food.

Doorenbos, J. and Kassam, A.H. (1979) Yield response to water, FAO Drainage and Irrigation Paper 33, Food and Agriculture Organization, Rome, Italy.

FAO (2003). Review of world water resources by country, FAO water report No.23, Food and Agriculture Organization, Rome, Italy.

FAO (2009) FAOSTAT on-line database, Food and Agriculture Organization, Rome, Italy, http://faostat.fao.org

FAO (2012) Cropping with water scarcity, FAO water report No. 38, Food and Agriculture Organization, Rome, Italy.

Garrido A., Llamas, R. Varela-Ortega, C. Novo, P. Rodríguez-Casado, R. and Aldaya, M. M. (2010) Water footprint and virtual water trade in Spain: Policy implications, Springer, New York, USA.

Hoekstra, A. Y. (2013) The water footprint of modern consumer society, Routledge, London, UK.

Hoekstra, A.Y. and Chapagain, A.K. (2008) Globalization of water: Sharing the planet's freshwater resources, Blackwell Publishing, Oxford, UK.

Hoekstra, A.Y. and Mekonnen, M.M. (2012) The water footprint of humanity, Proceedings of the National Academy of Sciences, 109(9): 3232-3237.

Hoekstra, A.Y., Chapagain, A.K., Aldaya, M.M. and Mekonnen, M.M. (2011) The water footprint assessment manual: Setting the global standard, Earthscan, London, UK.

Hoekstra, A.Y., Mekonnen, M.M., Chapagain, A.K., Mathews, R.E. and Richter, B.D. (2012) Global monthly water scarcity: Blue water footprints versus blue water availability, PLoS ONE 7(2): e32688.

Igbadun, H.E, Mahoo, H.F, Tarimo, A.K.P.R and Salim, B.A (2006) Crop water productivity of an irrigated maize crop in Mkoji sub-catchment of the great Ruaha River Basin, Tanzania, Agricultural Water Management, 85: 141-150. 
ITC (2007) SITA version 1996-2005 in SITC, [DVD-ROM], International trade centre, Geneva, Switzerland.

Kijne, J.W., Barker, R. and Molden, D. (2003) Water productivity in agriculture: limits and opportunities for development, IWMI and CABI Publisher, Wallingford, UK.

Mekonnen, M.M. and Hoekstra, A.Y. (2010) The green, blue and grey water footprint of crops and derived crop products, Value of Water Research Report Series No. 47, UNESCO-IHE, Delft, The Netherlands, ww.waterfootprint.org/Reports/Report47-WaterFootprintCrops-Vol1.pdf.

Mekonnen, M.M. and Hoekstra, A.Y. (2011a) National water footprint accounts: the green, blue and grey water footprint of production and consumption, Value of Water Research Report Series No. 50, UNESCO-IHE, Delft, The Netherlands, http://www.waterfootprint.org/Reports/Report50-NationalWaterFootprintsVol1.pdf.

Mekonnen, M.M. and Hoekstra, A.Y. (2011b) The green, blue and grey water footprint of crops and derived crop products, Hydrology and Earth System Sciences, 15(5): 1577-1600.

Ministry of Agriculture (2002) Ninth plan of development (1997-2001) (French), Tunis, Tunisia.

Ministry of Agriculture (2005a) Yearbook of surface water resources (French), General Directorate of Water Resources, Tunis, Tunisia.

Ministry of Agriculture (2005b) Yearbook of groundwater resources (French), General Directorate of Water Resources, Tunis, Tunisia.

Ministry of Environment (2009) Indicators for sustainable management of water resources (French), Tunis, Tunisia.

Molden, D. (2007) Water for food, Water for life: a comprehensive Assessment of Water Management in Agriculture, Earthscan London, UK, and IWMI, Colombo, Sri Lanka.

Molden, D., Oweis, T., Steduto, P., Bindraban, P., Hanjra, M.A. and Kijne, J. (2010) Improving agricultural Water productivity: Between optimism and caution, Agricultural Water Management, 97:528-535.

Oki T, Kanae S. (2006) Global hydrological cycles and world water resources, Science 313(5790): 1068-1072.

Palanisami, K ., Senthilvel, S., Ranganathan, C.R. , Ramesh, T. (2006) Water productivity at different scales under canal, tank and well irrigation systems, Centre for Agricultural and Rural Development Studies, Tamil Nadu Agricultural University, Coimbatore, India.

Pereira L.S., Cordery I., Iacovides I. (2009) Coping with water scarcity: Addressing the challenges, Springer, Dordrecht, the Netherlands.

Playan, E., Matoes, L. (2006) Modernization and optimization of irrigation systems to increase water productivity, Agricultural Water Management, 80: 100-116.

Rodrigues, G.C., Pereira, L.S. (2009) Assessing economic impacts of deficit irrigation as related to water productivity and water costs, Biosystems Engeneering, 103: 536-551.

Teixeira, A.H. de C., Bastiaanssen, W.G.M., Moura, M.S.B., Soares, J.M., Ahmad, M.D. and Bos, M.G. (2008) Energy and water balance measurement for water productivity analysis in irrigated mango trees, Northeast Brazil, Agricultural and Forest Meterology, 148: 1524-1537.

Vazifedoust, M., Van Dam, J.C., Feddes, R.A. and Feizi, M. (2008) Increasing water productivity of irrigated crops under limited water supply at field scale, Agricultural Water Management, 95: 89-102.

Vörösmarty, C.J., Green, P., Salisbury, J., and Lammers, R.B. (2000) Global water resources: vulnerability from climate change and population growth, Science 289: 284-288. 
Zwart, S.J., Bastiaanssen, W.G.M. (2004) Review of measured crop water productivity values for irrigated wheat, rice, cotton and maize, Agricultural Water Management, 69: 115-133.

Zwart, S.J., Bastiaanssen, W.G.M. (2007) SEBAL for detecting spatial variation of water productivity and scope for improvement in eight irrigated wheat systems, Agricultural Water Management, 89: 287-296. 
Appendix I: The average water footprint per ton of crop at regional and national level ( $\left.\mathrm{m}^{3} / \mathrm{ton}\right)$

Period 1996-2005

\begin{tabular}{|c|c|c|c|c|c|c|c|c|c|c|c|c|c|c|c|c|c|c|c|c|c|}
\hline \multirow{2}{*}{$\begin{array}{l}\text { Product } \\
\text { code } \\
\text { (FAOSAT) }\end{array}$} & \multirow{2}{*}{$\begin{array}{l}\text { Product } \\
\text { description } \\
\text { (FAOSTAT) }\end{array}$} & \multicolumn{4}{|c|}{ North } & \multicolumn{4}{|c|}{ Central } & \multicolumn{4}{|c|}{ South } & \multicolumn{4}{|c|}{ Tunisia average } & \multicolumn{4}{|c|}{ World average } \\
\hline & & Green & Blue & Grey & Total & Green & Blue & Grey & Total & Green & Blue & Grey & Total & Green & Blue & Grey & Total & Green & Blue & Grey & Total \\
\hline 15 & wheat & 2357 & 85 & 110 & 2552 & 2351 & 231 & 123 & 2705 & 2781 & 1227 & 211 & 4219 & 2375 & 72 & 109 & 2556 & 1277 & 342 & 207 & 1826 \\
\hline 44 & Barley & 3519 & 86 & 180 & 3785 & 3469 & 241 & 197 & 3907 & 3774 & 1047 & 306 & 5127 & 3561 & 75 & 181 & 3817 & 1213 & 79 & 131 & 1423 \\
\hline 75 & Oats & 26739 & 11325 & 1511 & 39575 & 27846 & 11058 & 1688 & 40592 & 40976 & 193 & 3437 & 44606 & 24687 & 13776 & 1458 & 39921 & 1479 & 181 & 128 & 1788 \\
\hline 83 & Sorghum & 10068 & 3520 & 506 & 14094 & 8048 & 5338 & 482 & 13868 & 10693 & 4158 & 833 & 15684 & 9708 & 3958 & 493 & 14159 & 2857 & 103 & 87 & 3047 \\
\hline 97 & Triticale & 801 & 0 & 90 & 891 & 793 & 3 & 90 & 886 & 984 & 0 & 97 & 1081 & 803 & 1 & 89 & 893 & 826 & 38 & 89 & 953 \\
\hline 108 & Cereals,nes & 227 & 2278 & 0 & 2505 & 2640 & 1983 & 0 & 4623 & 4636 & 23 & 0 & 4659 & 1907 & 2676 & 0 & 4583 & 3316 & 115 & 9 & 3440 \\
\hline 116 & Potatoes & 125 & 112 & 21 & 258 & 110 & 134 & 22 & 266 & 65 & 213 & 28 & 306 & 114 & 122 & 20 & 256 & 191 & 33 & 63 & 287 \\
\hline 157 & Sugar beet & 52 & 49 & 28 & 129 & 44 & 50 & 28 & 122 & 0 & 0 & 0 & 0 & 54 & 47 & 28 & 129 & 82 & 26 & 25 & 133 \\
\hline 176 & Beans, dry & 2524 & 97 & 465 & 3086 & 2242 & 194 & 457 & 2893 & 1422 & 318 & 454 & 2194 & 2510 & 102 & 455 & 3067 & 3945 & 125 & 983 & 5053 \\
\hline 181 & $\begin{array}{l}\text { Broad beans, } \\
\text { horse }\end{array}$ & 1961 & 85 & 378 & 2424 & 1722 & 232 & 377 & 2331 & 1128 & 226 & 433 & 1787 & 1978 & 64 & 372 & 2414 & 1317 & 205 & 496 & 2018 \\
\hline 187 & Peas, dry & 2868 & 65 & 426 & 3359 & 3175 & 88 & 526 & 3789 & 2770 & 606 & 724 & 4100 & 2899 & 55 & 424 & 3378 & 1453 & 33 & 493 & 1979 \\
\hline 201 & Lentils & 5860 & 254 & 736 & 6850 & 5701 & 267 & 780 & 6748 & 2758 & 1145 & 699 & 4602 & 5915 & 224 & 725 & 6864 & 4324 & 489 & 1060 & 5873 \\
\hline 205 & Vetches & 2620 & 60 & 404 & 3084 & 2833 & 163 & 494 & 3490 & 2171 & 367 & 624 & 3162 & 2613 & 60 & 396 & 3069 & 2031 & 109 & 213 & 2353 \\
\hline 211 & Pulses nes & 1682 & 50 & 264 & 1996 & 1850 & 65 & 324 & 2239 & 1226 & 345 & 353 & 1924 & 1697 & 43 & 262 & 2002 & 2217 & 250 & 650 & 3117 \\
\hline 221 & $\begin{array}{l}\text { Almonds, with } \\
\text { shell }\end{array}$ & 16598 & 2484 & 1005 & 20087 & 18290 & 1488 & 1201 & 20979 & 20813 & 2330 & 2079 & 25222 & 17763 & 1950 & 1105 & 20818 & 4632 & 1908 & 1507 & 8047 \\
\hline 223 & Pistachios & 69228 & 27982 & 4876 & 102086 & 73679 & 15743 & 5599 & 95021 & 58373 & 8713 & 7827 & 74913 & 80863 & 12022 & 5480 & 98365 & 3095 & 7602 & 666 & 11363 \\
\hline 260 & Olives & 8652 & 396 & 36 & 9084 & 8839 & 467 & 39 & 9345 & 10752 & 928 & 76 & 11756 & 8790 & 325 & 37 & 9152 & 2470 & 499 & 45 & 3014 \\
\hline 267 & Sunflower seed & 3069 & 0 & 23 & 3092 & 3091 & 0 & 24 & 3115 & 3212 & 0 & 40 & 3252 & 3093 & 0 & 23 & 3116 & 3017 & 148 & 201 & 3366 \\
\hline 270 & Rapeseed & 4127 & 0 & 30 & 4157 & 4183 & 0 & 32 & 4215 & 4111 & 0 & 51 & 4162 & 4173 & 0 & 30 & 4203 & 1703 & 231 & 336 & 2270 \\
\hline 328 & Seed cotton & 2505 & 0 & 738 & 3243 & 395 & 0 & 129 & 524 & 0 & 0 & 0 & 0 & 2515 & 0 & 736 & 3251 & 2282 & 1306 & 440 & 4028 \\
\hline 333 & Linseed & 1359 & 15 & 0 & 1374 & 1337 & 44 & 0 & 1381 & 1500 & 2 & 0 & 1502 & 1349 & 25 & 0 & 1374 & 4730 & 268 & 170 & 5168 \\
\hline 358 & $\begin{array}{l}\text { Cabbages and } \\
\text { other brassicas }\end{array}$ & 185 & 185 & 21 & 391 & 232 & 143 & 27 & 402 & 359 & 10 & 79 & 448 & 175 & 200 & 20 & 395 & 181 & 26 & 73 & 280 \\
\hline 366 & Artichokes & 625 & 87 & 37 & 749 & 540 & 200 & 36 & 776 & 353 & 397 & 53 & 803 & 614 & 106 & 36 & 756 & 478 & 242 & 98 & 818 \\
\hline 373 & Spinash & 114 & 12 & 22 & 148 & 110 & 16 & 23 & 149 & 144 & 0 & 45 & 189 & 110 & 17 & 21 & 148 & 118 & 14 & 160 & 292 \\
\hline
\end{tabular}




\begin{tabular}{|c|c|c|c|c|c|c|c|c|c|c|c|c|c|c|c|c|c|c|c|c|c|}
\hline \multirow{2}{*}{$\begin{array}{l}\text { Product } \\
\text { code } \\
\text { (FAOSAT) }\end{array}$} & \multirow{2}{*}{$\begin{array}{l}\text { Product description } \\
\text { (FAOSTAT) }\end{array}$} & \multicolumn{4}{|c|}{ North } & \multicolumn{4}{|c|}{ Central } & \multicolumn{4}{|c|}{ South } & \multicolumn{4}{|c|}{ Tunisia average } & \multicolumn{4}{|c|}{ World average } \\
\hline & & Green & Blue & Grey & Total & Green & Blue & Grey & Total & Green & Blue & Grey & Total & Green & Blue & Grey & Total & Green & Blue & Grey & Total \\
\hline 388 & Tomatoes & 69 & 39 & 8 & 116 & 76 & 36 & 9 & 121 & 149 & 1 & 23 & 173 & 60 & 48 & 8 & 116 & 108 & 63 & 43 & 214 \\
\hline 393 & $\begin{array}{l}\text { Cauliflowes and } \\
\text { brocolli }\end{array}$ & 82 & 4 & 15 & 101 & 79 & 7 & 15 & 101 & 99 & 0 & 28 & 127 & 80 & 6 & 15 & 101 & 189 & 21 & 75 & 285 \\
\hline 394 & $\begin{array}{l}\text { Pumpkins } \\
\text { squash and } \\
\text { grouds }\end{array}$ & 153 & 2 & 31 & 186 & 151 & 4 & 31 & 186 & 152 & 37 & 33 & 222 & 153 & 2 & 31 & 186 & 228 & 24 & 84 & 336 \\
\hline 399 & $\begin{array}{l}\text { Eggplants } \\
\text { (aubergines) }\end{array}$ & 134 & 4 & 18 & 156 & 131 & 6 & 18 & 155 & 174 & 1 & 27 & 202 & 133 & 5 & 18 & 156 & 234 & 33 & 95 & 362 \\
\hline 401 & $\begin{array}{l}\text { Chillies and } \\
\text { peppers, green }\end{array}$ & 158 & 5 & 22 & 185 & 156 & 7 & 23 & 186 & 214 & 0 & 40 & 254 & 157 & 7 & 22 & 186 & 240 & 42 & 97 & 379 \\
\hline 402 & $\begin{array}{l}\text { Onions (inc. } \\
\text { shallots), green }\end{array}$ & 62 & 12 & 12 & 86 & 62 & 13 & 13 & 88 & 106 & 0 & 34 & 140 & 59 & 15 & 12 & 86 & 176 & 44 & 51 & 271 \\
\hline 403 & Onions, dry & 199 & 66 & 17 & 282 & 214 & 62 & 21 & 297 & 422 & 8 & 77 & 507 & 189 & 77 & 17 & 283 & 192 & 88 & 65 & 345 \\
\hline 414 & Beans, green & 187 & 2 & 41 & 230 & 181 & 9 & 42 & 232 & 252 & 0 & 75 & 327 & 186 & 5 & 42 & 233 & 320 & 54 & 188 & 562 \\
\hline 417 & Peas, green & 309 & 4 & 54 & 367 & 295 & 16 & 55 & 366 & 411 & 1 & 90 & 502 & 304 & 9 & 54 & 367 & 382 & 63 & 150 & 595 \\
\hline 426 & $\begin{array}{l}\text { Carrots and } \\
\text { turnips }\end{array}$ & 285 & 500 & 35 & 820 & 487 & 384 & 65 & 936 & 674 & 29 & 152 & 855 & 260 & 529 & 33 & 822 & 106 & 28 & 61 & 195 \\
\hline 463 & $\begin{array}{l}\text { Vegetables fresh } \\
\text { nes }\end{array}$ & 147 & 6 & 21 & 174 & 143 & 9 & 22 & 174 & 205 & 1 & 46 & 252 & 144 & 9 & 21 & 174 & 205 & 33 & 101 & 339 \\
\hline 490 & Oranges & 373 & 218 & 22 & 613 & 374 & 235 & 24 & 633 & 214 & 506 & 26 & 746 & 367 & 228 & 22 & 617 & 401 & 110 & 49 & 560 \\
\hline 495 & $\begin{array}{c}\text { Tangerines, } \\
\text { mandarins, clem. }\end{array}$ & 551 & 322 & 33 & 906 & 553 & 348 & 36 & 937 & 317 & 748 & 38 & 1103 & 543 & 337 & 32 & 912 & 479 & 118 & 152 & 749 \\
\hline 497 & $\begin{array}{l}\text { Lemons and } \\
\text { limes }\end{array}$ & 305 & 178 & 18 & 501 & 306 & 192 & 20 & 518 & 175 & 414 & 21 & 610 & 311 & 193 & 18 & 522 & 432 & 152 & 58 & 642 \\
\hline 507 & $\begin{array}{c}\text { Grapefruit } \\
\text { (inc.pomelos) }\end{array}$ & 233 & 136 & 14 & 383 & 235 & 147 & 15 & 397 & 133 & 315 & 16 & 464 & 229 & 142 & 14 & 385 & 367 & 85 & 54 & 506 \\
\hline 512 & Citrus fruit, nes & 456 & 260 & 27 & 743 & 459 & 280 & 29 & 768 & 264 & 610 & 32 & 906 & 445 & 276 & 26 & 747 & 1145 & 62 & 35 & 1242 \\
\hline 526 & Apricots & 1720 & 0 & 93 & 1813 & 1785 & 0 & 105 & 1890 & 2191 & 0 & 198 & 2389 & 1761 & 0 & 98 & 1859 & 694 & 502 & 92 & 1288 \\
\hline 531 & Cherries & 285 & 0 & 8 & 293 & 109 & 0 & 6 & 115 & 128 & 0 & 12 & 140 & 107 & 0 & 6 & 113 & 961 & 531 & 112 & 1604 \\
\hline 534 & $\begin{array}{l}\text { Peaches and } \\
\text { nectarines }\end{array}$ & 1110 & 0 & 60 & 1170 & 1149 & 0 & 68 & 1217 & 1410 & 0 & 127 & 1537 & 1120 & 0 & 63 & 1183 & 583 & 188 & 139 & 910 \\
\hline
\end{tabular}




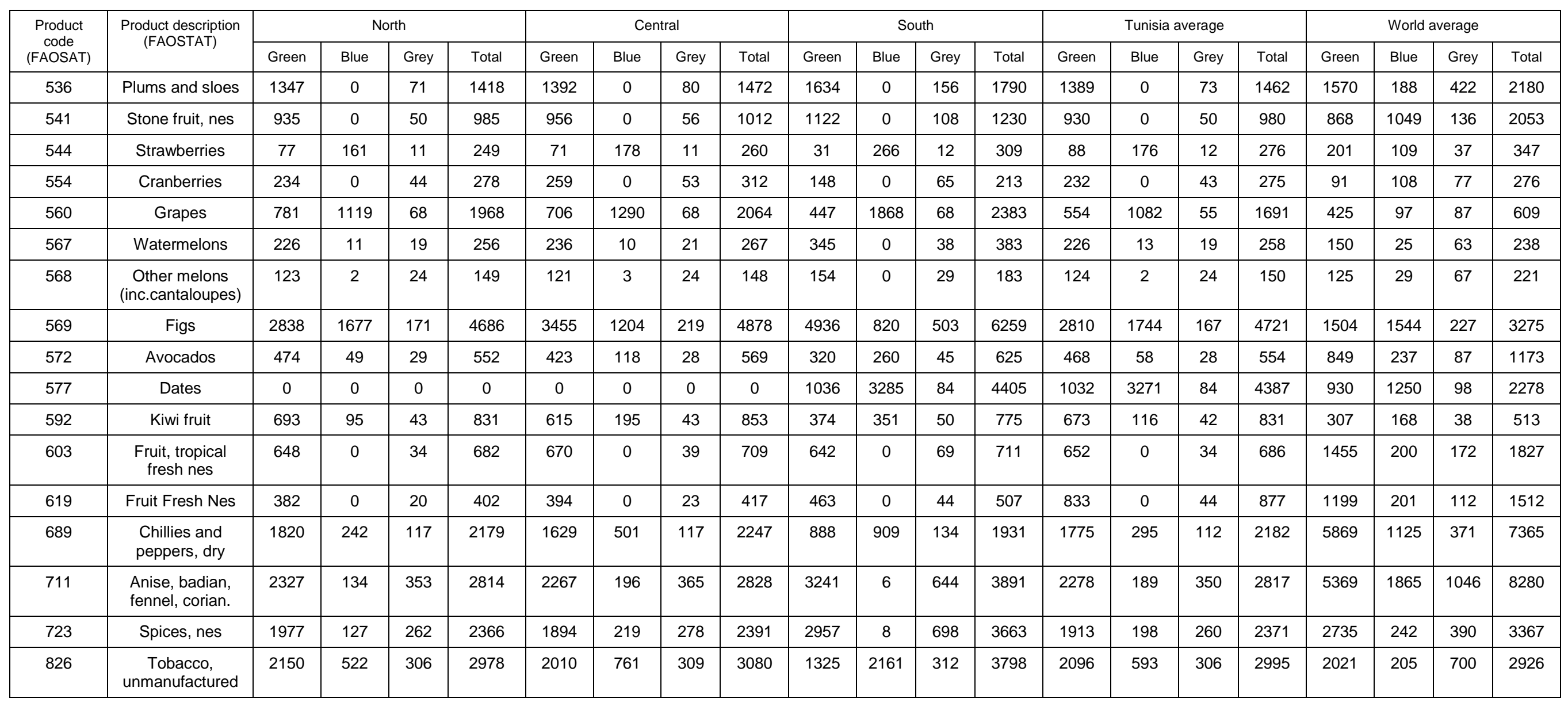

Source: Mekonnen and Hoekstra (2011) 
Appendix II: The total water footprint of crop production $\left(\mathrm{Mm}^{3} / \mathrm{yr}\right)$

\begin{tabular}{|c|c|c|c|c|c|c|c|c|c|c|c|c|c|c|c|c|c|}
\hline \multirow{2}{*}{$\begin{array}{l}\text { Product code } \\
\text { (FAOSAT) }\end{array}$} & \multirow{2}{*}{$\begin{array}{l}\text { Product description } \\
\text { (FAOSTAT) }\end{array}$} & \multicolumn{4}{|c|}{ North } & \multicolumn{4}{|c|}{ Central } & \multicolumn{4}{|c|}{ South } & \multicolumn{4}{|c|}{ Tunisia Total } \\
\hline & & Green & Blue & Grey & Total & Green & Blue & Grey & Total & Green & Blue & Grey & Total & Green & Blue & Grey & Total \\
\hline 15 & Wheat & 2820,1 & 71,0 & 128,5 & 3019,6 & 350,7 & 23,9 & 17,5 & 392,0 & 2,5 & 1,1 & 0,2 & 3,8 & 3173,2 & 95,9 & 146,2 & 3415,3 \\
\hline 44 & Barley & 926,4 & 14,4 & 46,6 & 987,3 & 289,3 & 10,7 & 15,2 & 315,2 & 2,2 & 0,6 & 0,2 & 3,0 & 1217,9 & 25,7 & 62,0 & 1305,6 \\
\hline 75 & Oats & 19,7 & 9,8 & 1,1 & 30,7 & 4,9 & 4,0 & 0,3 & 9,3 & 0,0 & 0,0 & 0,0 & 0,0 & 24,7 & 13,8 & 1,5 & 39,9 \\
\hline 83 & Sorghum & 9,1 & 3,5 & 0,5 & 13,0 & 0,6 & 0,5 & 0,0 & 1,2 & 0,0 & 0,0 & 0,0 & 0,0 & 9,7 & 4,0 & 0,5 & 14,2 \\
\hline 97 & Triticale & 4,2 & 0,0 & 0,5 & 4,7 & 1,2 & 0,0 & 0,1 & 1,3 & 0,0 & 0,0 & 0,0 & 0,0 & 5,4 & 0,0 & 0,6 & 6,0 \\
\hline 108 & Cereals, nes & 48,9 & 62,0 & 0,0 & 111,0 & 11,9 & 23,3 & 0,0 & 35,2 & 0,0 & 0,0 & 0,0 & 0,0 & 60,8 & 85,4 & 0,0 & 146,2 \\
\hline 116 & Potatoes & 33,5 & 35,0 & 5,8 & 74,3 & 1,8 & 2,6 & 0,4 & 4,8 & 0,0 & 0,0 & 0,0 & 0,0 & 35,3 & 37,7 & 6,2 & 79,1 \\
\hline 157 & Sugar beet & 4,4 & 3,9 & 2,3 & 10,5 & 0,0 & 0,1 & 0,0 & 0,1 & 0,0 & 0,0 & 0,0 & 0,0 & 4,4 & 3,9 & 2,3 & 10,7 \\
\hline 176 & Beans, dry & 1,1 & 0,0 & 0,2 & 1,4 & 0,0 & 0,0 & 0,0 & 0,0 & 0,0 & 0,0 & 0,0 & 0,0 & 1,2 & 0,0 & 0,2 & 1,4 \\
\hline 181 & Broad beans, horse & 68,1 & 2,1 & 12,8 & 83,0 & 1,1 & 0,1 & 0,2 & 1,4 & 0,0 & 0,0 & 0,0 & 0,0 & 69,2 & 2,3 & 13,0 & 84,5 \\
\hline 187 & Peas, dry & 14,6 & 0,3 & 2,1 & 17,1 & 1,2 & 0,0 & 0,2 & 1,4 & 0,0 & 0,0 & 0,0 & 0,0 & 15,8 & 0,3 & 2,3 & 18,5 \\
\hline 191 & Chick peas & 24,7 & 0,1 & 3,8 & 28,6 & 0,6 & 0,0 & 0,1 & 0,7 & 0,0 & 0,0 & 0,0 & 0,0 & 25,2 & 0,1 & 3,9 & 29,3 \\
\hline 201 & Lentils & 4,7 & 0,2 & 0,6 & 5,5 & 0,4 & 0,0 & 0,0 & 0,4 & 0,0 & 0,0 & 0,0 & 0,0 & 5,1 & 0,2 & 0,6 & 5,9 \\
\hline 205 & Vetches & 0,5 & 0,0 & 0,1 & 0,5 & 0,0 & 0,0 & 0,0 & 0,0 & 0,0 & 0,0 & 0,0 & 0,0 & 0,5 & 0,0 & 0,1 & 0,6 \\
\hline 211 & Pulses nes & 37,3 & 1,0 & 5,7 & 44,0 & 3,0 & 0,1 & 0,5 & 3,6 & 0,0 & 0,0 & 0,0 & 0,0 & 40,4 & 1,0 & 6,2 & 47,6 \\
\hline 221 & Almonds, with shell & 376,2 & 55,7 & 23,0 & 454,8 & 411,1 & 30,8 & 25,7 & 467,6 & 7,1 & 0,8 & 0,7 & 8,6 & 794,4 & 87,2 & 49,4 & 931,0 \\
\hline 223 & Pistachios & 35,7 & 10,2 & 2,4 & 48,3 & 69,4 & 5,4 & 4,6 & 79,5 & 0,9 & 0,1 & 0,1 & 1,1 & 105,9 & 15,7 & 7,2 & 128,9 \\
\hline 260 & Olives & 4660,8 & 170,3 & 19,1 & 4850,2 & 2581,5 & 95,6 & 11,3 & 2688,4 & 31,7 & 2,7 & 0,2 & 34,6 & 7274,0 & 268,6 & 30,6 & 7573,2 \\
\hline 267 & Sunflower seed & 28,5 & 0,0 & 0,2 & 28,7 & 2,2 & 0,0 & 0,0 & 2,2 & 0,0 & 0,0 & 0,0 & 0,0 & 30,8 & 0,0 & 0,2 & 31,0 \\
\hline 270 & Rapeseed & 7,9 & 0,0 & 0,1 & 7,9 & 1,0 & 0,0 & 0,0 & 1,0 & 0,0 & 0,0 & 0,0 & 0,0 & 8,8 & 0,0 & 0,1 & 8,9 \\
\hline 328 & Seed cotton & 7,9 & 0,0 & 2,3 & 10,2 & 0,1 & 0,0 & 0,0 & 0,2 & 0,0 & 0,0 & 0,0 & 0,0 & 8,0 & 0,0 & 2,3 & 10,3 \\
\hline 333 & Linseed & 5,0 & 0,1 & 0,0 & 5,0 & 1,4 & 0,1 & 0,0 & 1,4 & 0,0 & 0,0 & 0,0 & 0,0 & 6,3 & 0,1 & 0,0 & 6,5 \\
\hline 358 & Cabbages & 1,8 & 1,9 & 0,2 & 3,9 & 0,5 & 0,7 & 0,1 & 1,3 & 0,0 & 0,0 & 0,0 & 0,0 & 2,3 & 2,7 & 0,3 & 5,3 \\
\hline 366 & Artichokes & 9,7 & 1,2 & 0,6 & 11,5 & 1,0 & 0,6 & 0,1 & 1,7 & 0,0 & 0,0 & 0,0 & 0,0 & 10,7 & 1,9 & 0,6 & 13,2 \\
\hline 372 & Lettuce and chicory & 0,7 & 0,1 & 0,1 & 0,9 & 0,2 & 0,0 & 0,0 & 0,3 & 0,0 & 0,0 & 0,0 & 0,0 & 0,9 & 0,1 & 0,2 & 1,2 \\
\hline 373 & Spinach & 1,0 & 0,1 & 0,2 & 1,4 & 0,3 & 0,1 & 0,1 & 0,4 & 0,0 & 0,0 & 0,0 & 0,0 & 1,3 & 0,2 & 0,3 & 1,7 \\
\hline
\end{tabular}




\begin{tabular}{|c|c|c|c|c|c|c|c|c|c|c|c|c|c|c|c|c|c|}
\hline \multirow{2}{*}{$\begin{array}{l}\text { Product code } \\
\text { (FAOSAT) }\end{array}$} & \multirow{2}{*}{$\begin{array}{l}\text { Product description } \\
\text { (FAOSTAT) }\end{array}$} & \multicolumn{4}{|c|}{ North } & \multicolumn{4}{|c|}{ Central } & \multicolumn{4}{|c|}{ South } & \multicolumn{4}{|c|}{ Tunisia Total } \\
\hline & & Green & Blue & Grey & Total & Green & Blue & Grey & Total & Green & Blue & Grey & Total & Green & Blue & Grey & Total \\
\hline 388 & Tomatoes & 39,9 & 29,1 & 5,1 & 74,1 & 11,2 & 11,3 & 1,6 & 24,1 & 0,0 & 0,0 & 0,0 & 0,0 & 51,1 & 40,4 & 6,7 & 98,3 \\
\hline 393 & $\begin{array}{l}\text { Cauliflowers and } \\
\text { broccoli }\end{array}$ & 0,5 & 0,0 & 0,1 & 0,6 & 0,1 & 0,0 & 0,0 & 0,2 & 0,0 & 0,0 & 0,0 & 0,0 & 0,6 & 0,0 & 0,1 & 0,7 \\
\hline 394 & Pumpkins & 4,7 & 0,1 & 0,9 & 5,6 & 0,6 & 0,0 & 0,1 & 0,8 & 0,0 & 0,0 & 0,0 & 0,0 & 5,3 & 0,1 & 1,1 & 6,5 \\
\hline 397 & Cucumbers & 2,0 & 2,2 & 0,3 & 4,5 & 0,6 & 0,8 & 0,1 & 1,5 & 0,0 & 0,0 & 0,0 & 0,0 & 2,6 & 3,0 & 0,4 & 6,0 \\
\hline 399 & $\begin{array}{l}\text { Eggplants } \\
\text { (aubergines) }\end{array}$ & 0,0 & 0,0 & 0,0 & 0,0 & 0,0 & 0,0 & 0,0 & 0,0 & 0,0 & 0,0 & 0,0 & 0,0 & 0,0 & 0,0 & 0,0 & 0,0 \\
\hline 401 & $\begin{array}{l}\text { Chillies and peppers, } \\
\text { green }\end{array}$ & 25,7 & 0,9 & 3,6 & 30,1 & 8,1 & 0,7 & 1,2 & 10,0 & 0,0 & 0,0 & 0,0 & 0,0 & 33,7 & 1,5 & 4,8 & 40,1 \\
\hline 402 & $\begin{array}{l}\text { Onions (incl. shallots), } \\
\text { green }\end{array}$ & 6,0 & 1,3 & 1,2 & 8,5 & 1,5 & 0,6 & 0,3 & 2,5 & 0,0 & 0,0 & 0,0 & 0,0 & 7,5 & 2,0 & 1,5 & 11,0 \\
\hline 403 & Onions, dry & 17,3 & 6,3 & 1,5 & 25,0 & 5,0 & 2,8 & 0,5 & 8,2 & 0,0 & 0,0 & 0,0 & 0,0 & 22,2 & 9,0 & 2,0 & 33,3 \\
\hline 406 & Garlic & 5,1 & 2,0 & 0,5 & 7,6 & 1,5 & 0,9 & 0,2 & 2,5 & 0,0 & 0,0 & 0,0 & 0,0 & 6,6 & 2,9 & 0,6 & 10,1 \\
\hline 414 & Beans, green & 0,4 & 0,0 & 0,1 & 0,4 & 0,1 & 0,0 & 0,0 & 0,1 & 0,0 & 0,0 & 0,0 & 0,0 & 0,5 & 0,0 & 0,1 & 0,6 \\
\hline 417 & Peas, green & 3,9 & 0,1 & 0,7 & 4,6 & 1,0 & 0,1 & 0,2 & 1,3 & 0,0 & 0,0 & 0,0 & 0,0 & 4,9 & 0,1 & 0,9 & 5,9 \\
\hline 426 & Carrots and turnips & 9,2 & 17,8 & 1,1 & 28,2 & 2,8 & 6,7 & 0,4 & 9,9 & 0,0 & 0,0 & 0,0 & 0,0 & 12,1 & 24,5 & 1,5 & 38,1 \\
\hline 461 & Carobs & 0,0 & 0,0 & 0,0 & 0,0 & 3,6 & 0,1 & 0,1 & 3,8 & 0,0 & 0,0 & 0,0 & 0,0 & 3,6 & 0,1 & 0,1 & 3,8 \\
\hline 463 & Vegetables fresh nes & 8,4 & 0,4 & 1,2 & 9,9 & 2,5 & 0,3 & 0,4 & 3,1 & 0,0 & 0,0 & 0,0 & 0,0 & 10,8 & 0,7 & 1,6 & 13,1 \\
\hline 490 & Oranges & 35,9 & 21,6 & 2,1 & 59,5 & 3,3 & 2,7 & 0,2 & 6,3 & 0,0 & 0,1 & 0,0 & 0,1 & 39,2 & 24,3 & 2,3 & 65,9 \\
\hline 495 & $\begin{array}{l}\text { Tangerines, } \\
\text { mandarins }\end{array}$ & 18,2 & 11,0 & 1,1 & 30,3 & 1,7 & 1,4 & 0,1 & 3,2 & 0,0 & 0,0 & 0,0 & 0,0 & 20,0 & 12,4 & 1,2 & 33,5 \\
\hline 497 & Lemons and limes & 5,6 & 3,4 & 0,3 & 9,3 & 0,5 & 0,4 & 0,0 & 1,0 & 0,0 & 0,0 & 0,0 & 0,0 & 6,1 & 3,8 & 0,4 & 10,3 \\
\hline 507 & Grapefruit & 12,6 & 7,6 & 0,7 & 21,0 & 1,2 & 1,0 & 0,1 & 2,2 & 0,0 & 0,0 & 0,0 & 0,0 & 13,8 & 8,6 & 0,8 & 23,2 \\
\hline 512 & Citrus fruit, nes & 25,1 & 15,0 & 1,5 & 41,5 & 2,3 & 1,9 & 0,1 & 4,3 & 0,0 & 0,0 & 0,0 & 0,1 & 27,4 & 16,9 & 1,6 & 45,9 \\
\hline 515 & Apples & 105,8 & 0,0 & 5,5 & 111,3 & 21,1 & 0,0 & 1,2 & 22,3 & 0,3 & 0,0 & 0,0 & 0,3 & 127,2 & 0,0 & 6,7 & 133,9 \\
\hline 521 & Pears & 55,1 & 0,0 & 2,9 & 58,0 & 11,0 & 0,0 & 0,6 & 11,6 & 0,0 & 0,0 & 0,0 & 0,0 & 66,1 & 0,0 & 3,5 & 69,6 \\
\hline 526 & Apricots & 17,4 & 0,0 & 0,9 & 18,4 & 30,0 & 0,0 & 1,7 & 31,7 & 0,1 & 0,0 & 0,0 & 0,1 & 47,5 & 0,0 & 2,6 & 50,1 \\
\hline 534 & $\begin{array}{l}\text { Peaches and } \\
\text { nectarines }\end{array}$ & 68,6 & 0,0 & 3,8 & 72,3 & 18,4 & 0,0 & 1,1 & 19,5 & 0,1 & 0,0 & 0,0 & 0,1 & 87,0 & 0,0 & 4,9 & 91,9 \\
\hline
\end{tabular}




\begin{tabular}{|c|c|c|c|c|c|c|c|c|c|c|c|c|c|c|c|c|c|}
\hline \multirow{2}{*}{$\begin{array}{l}\text { Product code } \\
\text { (FAOSAT) }\end{array}$} & \multirow{2}{*}{$\begin{array}{l}\text { Product description } \\
\text { (FAOSTAT) }\end{array}$} & \multicolumn{4}{|c|}{ North } & \multicolumn{4}{|c|}{ Central } & \multicolumn{4}{|c|}{ South } & \multicolumn{4}{|c|}{ Tunisia Total } \\
\hline & & Green & Blue & Grey & Total & Green & Blue & Grey & Total & Green & Blue & Grey & Total & Green & Blue & Grey & Total \\
\hline 536 & Plums and sloes & 15,8 & 0,0 & 0,8 & 16,6 & 3,1 & 0,0 & 0,2 & 3,3 & 0,0 & 0,0 & 0,0 & 0,0 & 19,0 & 0,0 & 1,0 & 20,0 \\
\hline 541 & Stone fruit, nes & 2,6 & 0,0 & 0,1 & 2,7 & 0,2 & 0,0 & 0,0 & 0,2 & 0,0 & 0,0 & 0,0 & 0,0 & 2,8 & 0,0 & 0,1 & 2,9 \\
\hline 544 & Strawberries & 0,6 & 1,2 & 0,1 & 1,8 & 0,0 & 0,1 & 0,0 & 0,2 & 0,0 & 0,0 & 0,0 & 0,0 & 0,6 & 1,3 & 0,1 & 2,0 \\
\hline 554 & Cranberries & 0,0 & 0,0 & 0,0 & 0,0 & 0,0 & 0,0 & 0,0 & 0,0 & 0,0 & 0,0 & 0,0 & 0,0 & 0,0 & 0,0 & 0,0 & 0,0 \\
\hline 560 & Grapes & 27,7 & 43,4 & 2,6 & 73,6 & 30,6 & 54,5 & 2,9 & 87,9 & 7,6 & 30,9 & 1,2 & 39,7 & 65,9 & 128,7 & 6,6 & 201,2 \\
\hline 567 & Watermelons & 59,0 & 3,0 & 5,0 & 66,9 & 17,2 & 1,4 & 1,6 & 20,2 & 0,2 & 0,0 & 0,0 & 0,2 & 76,3 & 4,5 & 6,6 & 87,4 \\
\hline 568 & Other melons & 8,6 & 0,1 & 1,6 & 10,3 & 2,6 & 0,1 & 0,5 & 3,2 & 0,0 & 0,0 & 0,0 & 0,0 & 11,2 & 0,2 & 2,2 & 13,6 \\
\hline 569 & Figs & 61,8 & 38,7 & 3,6 & 104,1 & 8,2 & 4,9 & 0,5 & 13,6 & 0,3 & 0,0 & 0,0 & 0,3 & 70,3 & 43,6 & 4,2 & 118,0 \\
\hline 572 & Avocados & 0,1 & 0,0 & 0,0 & 0,1 & 0,0 & 0,0 & 0,0 & 0,0 & 0,0 & 0,0 & 0,0 & 0,0 & 0,1 & 0,0 & 0,0 & 0,1 \\
\hline 577 & Dates & 0,0 & 0,0 & 0,0 & 0,0 & 0,0 & 0,0 & 0,0 & 0,0 & 109,9 & 348,5 & 8,9 & 467,4 & 109,9 & 348,5 & 8,9 & 467,4 \\
\hline 592 & Kiwi fruit & 0,0 & 0,0 & 0,0 & 0,0 & 0,0 & 0,0 & 0,0 & 0,0 & 0,0 & 0,0 & 0,0 & 0,0 & 0,0 & 0,0 & 0,0 & 0,0 \\
\hline 603 & $\begin{array}{c}\text { Fruit, tropical fresh } \\
\text { nes }\end{array}$ & 45,4 & 0,0 & 2,3 & 47,7 & 3,7 & 0,0 & 0,2 & 3,9 & 0,0 & 0,0 & 0,0 & 0,0 & 49,1 & 0,0 & 2,5 & 51,6 \\
\hline 619 & Fruit Fresh Nes & 45,1 & 0,0 & 2,3 & 47,5 & 9,0 & 0,0 & 0,5 & 9,5 & 0,1 & 0,0 & 0,0 & 0,1 & 54,3 & 0,0 & 2,9 & 57,1 \\
\hline 689 & $\begin{array}{l}\text { Chillies and peppers, } \\
\text { dry }\end{array}$ & 11,2 & 1,3 & 0,7 & 13,3 & 1,2 & 0,7 & 0,1 & 2,0 & 0,0 & 0,0 & 0,0 & 0,0 & 12,4 & 2,1 & 0,8 & 15,3 \\
\hline 711 & Anise, badian, fennel & 17,6 & 1,1 & 2,6 & 21,4 & 4,5 & 0,7 & 0,8 & 6,0 & 0,0 & 0,0 & 0,0 & 0,0 & 22,2 & 1,8 & 3,4 & 27,4 \\
\hline 723 & Spices, nes & 3,4 & 0,2 & 0,4 & 4,0 & 0,8 & 0,2 & 0,1 & 1,1 & 0,0 & 0,0 & 0,0 & 0,0 & 4,2 & 0,4 & 0,6 & 5,2 \\
\hline 826 & Tobacco & 4,6 & 1,2 & 0,7 & 6,5 & 1,5 & 0,6 & 0,2 & 2,3 & 0,0 & 0,0 & 0,0 & 0,0 & 6,1 & 1,7 & 0,9 & 8,7 \\
\hline 900 & Fodder crops & 728,6 & 0,0 & 20,9 & 749,5 & 57,2 & 0,0 & 1,8 & 59,0 & 0,6 & 0,0 & 0,0 & 0,6 & 786,4 & 0,0 & 22,8 & 809,1 \\
\hline \multicolumn{2}{|c|}{ Total WF (Mm3/yr) } & 10651,8 & 651,7 & 337,5 & 11641,1 & 4003,4 & 293,5 & 96,4 & 4393,2 & 163,9 & 385,0 & 11,7 & 560,6 & 14819 & 1330 & 446 & 16595 \\
\hline
\end{tabular}

Source: Mekonnen and Hoekstra (2011) 



\section{Value of Water Research Report Series}

Editorial board: A.Y. Hoekstra, University of Twente; H.H.G. Savenije, Delft University of Technology; P. van der Zaag, UNESCO-IHE.

1. Exploring methods to assess the value of water: A case study on the Zambezi basin

A.K. Chapagain - February 2000

2. Water value flows: A case study on the Zambezi basin.

A.Y. Hoekstra, H.H.G. Savenije and A.K. Chapagain -March 2000

3. The water value-flow concept

I.M. Seyam and A.Y. Hoekstra -December 2000

4. The value of irrigation water in Nyanyadzi smallholder irrigation scheme, Zimbabwe

G.T. Pazvakawambwa and P. van der Zaag - January 2001

5. The economic valuation of water: Principles and methods

J.I. Agudelo - August 2001

6. The economic valuation of water for agriculture: A simple method applied to the eight Zambezi basin countries J.I. Agudelo and A.Y. Hoekstra - August 2001

7. The value of freshwater wetlands in the Zambezi basin

I.M. Seyam, A.Y. Hoekstra, G.S. Ngabirano and H.H.G. Savenije - August 2001

8. 'Demand management' and 'Water as an economic good': Paradigms with pitfalls

H.H.G. Savenije and P. van der Zaag - October 2001

9. Why water is not an ordinary economic good

H.H.G. Savenije - October 2001

10. Calculation methods to assess the value of upstream water flows and storage as a function of downstream benefits I.M. Seyam, A.Y. Hoekstra and H.H.G. Savenije - October 2001

11. Virtual water trade: A quantification of virtual water flows between nations in relation to international crop trade A.Y. Hoekstra and P.Q. Hung - September 2002

12. Virtual water trade: Proceedings of the international expert meeting on virtual water trade A.Y. Hoekstra (ed.) - February 2003

13. Virtual water flows between nations in relation to trade in livestock and livestock products A.K. Chapagain and A.Y. Hoekstra - July 2003

14. The water needed to have the Dutch drink coffee A.K. Chapagain and A.Y. Hoekstra - August 2003

15. The water needed to have the Dutch drink tea A.K. Chapagain and A.Y. Hoekstra-August 2003

16. Water footprints of nations, Volume 1: Main Report, Volume 2: Appendices A.K. Chapagain and A.Y. Hoekstra - November 2004

17. Saving water through global trade A.K. Chapagain, A.Y. Hoekstra and H.H.G. Savenije - September 2005

18. The water footprint of cotton consumption A.K. Chapagain, A.Y. Hoekstra, H.H.G. Savenije and R. Gautam - September 2005

19. Water as an economic good: the value of pricing and the failure of markets P. van der Zaag and H.H.G. Savenije - July 2006

20. The global dimension of water governance: Nine reasons for global arrangements in order to cope with local water problems A.Y. Hoekstra - July 2006

21. The water footprints of Morocco and the Netherlands A.Y. Hoekstra and A.K. Chapagain - July 2006

22. Water's vulnerable value in Africa P. van der Zaag - July 2006

23. Human appropriation of natural capital: Comparing ecological footprint and water footprint analysis A.Y. Hoekstra - July 2007

24. A river basin as a common-pool resource: A case study for the Jaguaribe basin in Brazil P.R. van Oel, M.S. Krol and A.Y. Hoekstra - July 2007

25. Strategic importance of green water in international crop trade M.M. Aldaya, A.Y. Hoekstra and J.A. Allan - March 2008

26. Global water governance: Conceptual design of global institutional arrangements M.P. Verkerk, A.Y. Hoekstra and P.W. Gerbens-Leenes - March 2008

27. Business water footprint accounting: A tool to assess how production of goods and services impact on freshwater resources worldwide P.W. Gerbens-Leenes and A.Y. Hoekstra-March 2008

28. Water neutral: reducing and offsetting the impacts of water footprints A.Y. Hoekstra - March 2008

29. Water footprint of bio-energy and other primary energy carriers P.W. Gerbens-Leenes, A.Y. Hoekstra and Th.H. van der Meer-March 2008

30. Food consumption patterns and their effect on water requirement in China J. Liu and H.H.G. Savenije - March 2008

31. Going against the flow: A critical analysis of virtual water trade in the context of India's National River Linking Programme S. Verma, D.A. Kampman, P. van der Zaag and A.Y. Hoekstra-March 2008

32. The water footprint of India D.A. Kampman, A.Y. Hoekstra and M.S. Krol-May 2008 
33. The external water footprint of the Netherlands: Quantification and impact assessment P.R. van Oel, M.M. Mekonnen and A.Y. Hoekstra - May 2008

34. The water footprint of bio-energy: Global water use for bio-ethanol, bio-diesel, heat and electricity P.W. Gerbens-Leenes, A.Y. Hoekstra and Th.H. van der Meer-August 2008

35. Water footprint analysis for the Guadiana river basin M.M. Aldaya and M.R. Llamas - November 2008

36. The water needed to have Italians eat pasta and pizza M.M. Aldaya and A.Y. Hoekstra - May 2009

37. The water footprint of Indonesian provinces related to the consumption of crop products F. Bulsink, A.Y. Hoekstra and M.J. Booij-May 2009

38. The water footprint of sweeteners and bio-ethanol from sugar cane, sugar beet and maize P.W. Gerbens-Leenes and A.Y. Hoekstra-November 2009

39. A pilot in corporate water footprint accounting and impact assessment: The water footprint of a sugar-containing carbonated beverage A.E. Ercin, M.M. Aldaya and A.Y. Hoekstra - November 2009

40. The blue, green and grey water footprint of rice from both a production and consumption perspective A.K. Chapagain and A.Y. Hoekstra - March 2010

41. Water footprint of cotton, wheat and rice production in Central Asia M.M. Aldaya, G. Muñoz and A.Y. Hoekstra - March 2010

42. A global and high-resolution assessment of the green, blue and grey water footprint of wheat M.M. Mekonnen and A.Y. Hoekstra - April 2010

43. Biofuel scenarios in a water perspective: The global blue and green water footprint of road transport in 2030 A.R. van Lienden, P.W. Gerbens-Leenes, A.Y. Hoekstra and Th.H. van der Meer-April 2010

44. Burning water: The water footprint of biofuel-based transport P.W. Gerbens-Leenes and A.Y. Hoekstra - June 2010

45. Mitigating the water footprint of export cut flowers from the Lake Naivasha Basin, Kenya M.M. Mekonnen and A.Y. Hoekstra - June 2010

46. The green and blue water footprint of paper products: methodological considerations and quantification P.R. van Oel and A.Y. Hoekstra - July 2010

47. The green, blue and grey water footprint of crops and derived crop products M.M. Mekonnen and A.Y. Hoekstra - December 2010

48. The green, blue and grey water footprint of animals and derived animal products M.M. Mekonnen and A.Y. Hoekstra - December 2010

49. The water footprint of soy milk and soy burger and equivalent animal products A.E. Ercin, M.M. Aldaya and A.Y. Hoekstra - February 2011

50. National water footprint accounts: The green, blue and grey water footprint of production and consumption M.M. Mekonnen and A.Y. Hoekstra - May 2011

51. The water footprint of electricity from hydropower M.M. Mekonnen and A.Y. Hoekstra - June 2011

52. The relation between national water management and international trade: a case study from Kenya M.M. Mekonnen and A.Y. Hoekstra - June 2011

53. Global water scarcity: The monthly blue water footprint compared to blue water availability for the world's major river basins A.Y. Hoekstra and M.M. Mekonnen - September 2011

54. Proceedings of the ESF Strategic Workshop on accounting for water scarcity and pollution in the rules of international trade A.Y. Hoekstra, M.M. Aldaya and B. Avril (eds.) - October 2011

55. A comparative study on the water footprint of poultry, pork and beef in different countries and production systems P.W. Gerbens-Leenes, M.M. Mekonnen and A.Y. Hoekstra-December 2011

56. The water footprint of France

A.E. Ercin, M.M. Mekonnen and A.Y. Hoekstra - March 2012

57. The water footprint of Switzerland

A.E. Ercin, M.M. Mekonnen and A.Y. Hoekstra - March 2012

58. Blue water footprint of agriculture, industry, households and water management in the Netherlands A.Y. Hoekstra, M.J. Booij, J.C Hunink and K.S. Meijer - June 2012

59. Water footprint scenarios for 2050: A global analysis and case study for Europe A.E. Ercin and A.Y. Hoekstra - September 2012

60. Proceedings of the session "Solving the Water Crisis: Common Action Toward a Sustainable Water Footprint", Planet under Pressure Conference, London, 26 March 2012 G.P. Zhang, A.Y. Hoekstra and D. Tickner (eds.) - October 2012

61. Water footprint of Tunisia from an economic perspective H. Chouchane, A.Y. Hoekstra, M.S. Krol and M.M. Mekonnen-November 2013

Reports can be downloaded from: www.waterfootprint.org www.unesco-ihe.org/value-of-water-research-report-series 

UNESCO-IHE

P.O. Box 3015

2601 DA Delft

The Netherlands

Website www.unesco-ihe.org

Phone +31152151715

University of Twente

Delft University of Technology
UNESCO-IHE

Institute for Water Education
UNIVERSITY OF TWENTE.

TUDelft

Delft University of Technology 